\title{
A bibliometric review on development economics research in Vietnam from 2008 to 2020
}

\author{
Manh-Toan $\mathrm{Ho}^{1}$ D $\cdot$ Ngoc-Thang B. Le ${ }^{2}$ Manh-Tung Ho ${ }^{1} \cdot$ Quan-Hoang Vuong ${ }^{1}$
}

Accepted: 3 October 2021 / Published online: 12 October 2021

(c) The Author(s), under exclusive licence to Springer Nature B.V. 2021

\begin{abstract}
This study adopts the bibliometric approach to identify the key characteristics in the relationship of demographic factors (age, gender, affiliations, and locations), scientific productivity, and the collaboration among development economics researchers in Vietnam during the period 2008-2020. Overall, the number of publications and authors in development economics are rising steeply with the average annual growth rate of nearly $23 \%$ and $26 \%$, respectively. Moreover, the 'quality' of the research appears to be high as 59\% of the articles are published in journals in the first and second quartile according Scimago journal ranking. However, the citation counts for these studies indicate their impacts are far more languishing in comparison. In terms of research trends, this study identified three emerging areas of studies that are relatively under-researched, namely natural resources, technology, and urbanization. As for publishing practices, There is also a positive sign for the adoption of open science among Vietnamese researchers in this field. The findings are useful for predicting future research trends. In addition, the study provides several implications for policymakers in Vietnam to enhance research capacity.
\end{abstract}

Keywords Development economics · Bibliometrics · Vietnam scientific productivity · Open access

\section{Introduction}

Vietnam's economic reformation in 1986, known as Đổi mói i, has transformed the country into a vibrant market economy. In 2007, the World Trade Organization recognized Vietnam as one of its members, which resulted in a high inflow of foreign direct investment (FDI) of US\$71.7 billion in 2008 (Vuong 2019; Vuong et al. 2019). Vietnam also recorded a stable economic growth rate of $6.8 \%$ in $2017,7.1 \%$ in 2018 , and $7 \%$ in 2019. Even under the significant impact of the COVID-19 pandemic in 2020-2021, the country's growth rate is still expected to be around 2 to $2.5 \%$ (Thuy 2020b).

Manh-Toan Ho

toan.homanh@phenikaa-uni.edu.vn

1 Centre for Interdisciplinary Social Research, Phenikaa University, Hanoi, Viet Nam

2 College of Asia Pacific Studies, Ritsumeikan Asia Pacific University, Beppu, Oita 874-8577, Japan 
The high growth rate in recent years (Thuy 2020b; Vuong et al. 2019) and the swift response to the crisis ( $\mathrm{La}$ et al. 2020) have eased the uncertainties during the pandemic for Vietnam. In the 2021-2025 period, former Prime Minister Nguyen Xuan Phuc aimed for an ambitious average 7\% GDP growth rate (The National Assembly of Viet Nam 2016; Thuy 2020a). The fast-growing economy has benefited multiple sectors in the country, including science and technology research. In 2008, the National Foundation for Science and Technology Development (NAFOSTED) gained official status after its establishment in 2003 with the Decree 122/2003/NĐ-CP of the Government. Six years into its officialization, the Government issued the Decree 23/2014/NĐ-CP on April 3, 2014, to reform the rules of the NAFOSTED, with the mission to increase Vietnam's scientific and technological research capacity that matches international standards.

After 2008, the scientific productivity in Vietnam took off with a remarkable growth rate due to the support of NAFOSTED and new policies in 2014 and 2017 (Vuong et al. 2021). For instance, the growth rate of scientific publications from Vietnam in the Scopus or Web of Science (WoS) has continued at a high level, averaging $22.23 \%$ during the period 2008-2020 (Ho et al. 2020b; Ho 2015; Nguyen et al. 2017c). As such, a thorough overview of Vietnam's development economics landscape, a critical research field that looks at the various aspects of economic development in low-income countries, would unveil important insights for both the scientific community and the policymakers. Moreover, it also provides various perspectives on the research topics, data, or theories used in the field. Some of the important issues include the relationship of demographic factors (age, gender, affiliations, or locations) and scientific productivity and the collaboration among development economics researchers in Vietnam.

The main goals of the study can be achieved by the following steps. Firstly, a thorough literature review on the following issues is conducted: (i) development economics and bibliometrics studies on development economics research in the world; (ii) scientific research using a bibliometric approach in Vietnam. Secondly, based on the literature review, a list of keywords will be created. The keywords have to yield all essential aspects of development economics. Thirdly, based on availability, a popular and reliable source of data is chosen. In this study, with the focus on development economics research in Vietnam, the Social Sciences and Humanities Peer Awards database (SSHPA) - A database of Vietnamese social sciences and humanities' productivity, is a suitable option. The collected data from the SSHPA database will be cleaned, verified, and cross-checked manually to ensure quality.

In this study, a bibliometric approach is applied to demonstrate and visualize the development of the field. Based on the findings, recommendations and proposals for changes and future policies are suggested.

\section{Literature review}

\subsection{Development economics and bibliometric research}

The number of scientific publications has been rising considerably in recent years. More than one million articles are indexed in the PubMed database each year (Landhuis 2016), and many researchers publish a paper every 5 days (Ioannidis et al. 2018). Thus, scientists have to constantly update their methods to keep up with the growing volume of scientific papers. For instance, in medical research, Living Systematic Review was proposed as a 
practical solution for information overload (Elliott et al. 2014). In recent years, the advent of artificial intelligence also provides experimental tools to help scientists with updating the latest findings, sorting out papers, or even supporting the peer review process (Extance 2018; Heaven 2018). More conventionally, bibliometric databases like Web of Science or Scopus are important venues for researchers. The in-depth analysis of their data can provide essential insights into the development of science (Ellegaard and Wallin 2015). The well-known journal metrics from Web of Science and Scopus are considered as a simple type of bibliometric. However, using a mere number to rank a journal has many shortcomings and can be abused in various ways (Berenbaum 2019; Tran et al. 2020). Thus, in its reports, the Web of Science has to use more sophisticated methods to provide an overview of the scientific development in South and East Asia (Adams et al. 2019) or to identify hot topics and new research fronts (Szomszor et al. 2020).

Throughout the development of development economics research, scientists have used bibliometrics to explore different aspects of the field: the impact of prestigious journals (Madrueño and Tezanos 2018), the plans to achieve sustainable goals in different countries (Chimhowu et al. 2019), or the interdisciplinary nature of development economics (Mitra et al. 2020).

\subsection{Scientific research in Vietnam}

Development economics research in Vietnam has contributed significant studies on important topics in the country, notably poverty identification (Nguyen and Tran 2014), forest cover change (Van et al. 2020), social pension and the aging population (Giang and Pfau 2009), natural disasters and household welfare (Arouri et al. 2015), and poverty among ethnic minorities in Vietnam (Tran et al. 2015). However, there has not been a bibliometric study devoted to this important field.

The earliest effort to quantify Vietnam's scientific productivity goes back to 2010. Hien (2010) compared the performance of 11 countries in East and Southeast Asia by using various factors: number of publications in Web of Science per 1 million people, mean citation count, and domestic authors' involvement in the number of peer-review international publications per 1 million people. The early findings suggested that Vietnam was among low productivity countries, with only 9.3 papers per 1 million people. Moreover, Vietnamese authors relied heavily on international collaborators, and universities in Vietnam were not involved strongly in research production (Hien 2010).

In 2011, Nguyen and Pham (2011) found a strong positive relationship between scientific research and the degree of "knowledgization" of the economy. Four years later, (Ho 2015) used Scopus data to analyze the scientific productivity in Vietnam from 1996 to 2013. Since 2002, the total output of scientific publications in Vietnam has increased by $20 \%$ annually. However, the collaborated papers contributed about $77 \%$ of the total output, with the only exception in Mathematics. Even though the study subjects are mainly about Vietnam, Vietnamese corresponding authors' percentage was very low. On aggregate, Japan was Vietnam's largest scientific collaborator, followed by the United States, France, South Korea, and the United Kingdom. In the medical field, especially public health, the United States and the United Kingdom were the largest partners with Vietnam (Nguyen and Pham 2011).

According to Nguyen et al. (2017c)'s assessment of Vietnam's international scientific collaboration through WoS data, Vietnam published only 200-300 papers a year in ISI indexed journals during the 1990s. However, by 2015, this number had increased more 
than tenfold to almost 3000. Nevertheless, the contribution of Vietnam to the world's scientific output is still very modest (around $0.2 \%$ ) compared with the country's population size (around 1.2\% of the world's population) (Nguyen et al. 2017c). Furthermore, similar to (Ho 2015)'s findings, around $75 \%$ of the growth in Vietnam's scientific output in the past 15 years resulted from international collaborations, even though the share of internationally authored papers has slightly decreased over time (Nguyen et al. 2017c).

The early bibliometric analyses from Vietnamese authors used well-known databases such as Scopus (Ho 2015) or Web of Science (Hien 2010; Nguyen et al. 2017c), focused on a regional scale of East and Southeast Asia, and offered general insights into Vietnam's scientific productivity. In terms of research fields, they used the classification of the databases to measure the research output. The four articles (Hien 2010; Ho 2015; Nguyen et al. 2017c; Nguyen and Pham 2011) showed that natural science is still the dominant force in Vietnam. The dominance of hard science in Vietnam in the 1986-2008 period was due to the pioneering of mathematics research (Nguyen et al. 2021). The establishment of NAFOSTED in 2008 and the increasing focus on international publications have helped other fields gain more attention (Nguyen et al. 2021; Vuong et al. 2021).

The efforts to measure the scientific productivity of social sciences and humanities exclusively were only realized with the establishment of SSHPA in 2017. This open database quantifies and records data on research in the social science and humanities from 2008 onward. Such efforts have to be fruitful with foundational works in 2017 and early 2018 (Ho et al. 2017a,b; Vuong et al. 2018), a data article in 2018 (Vuong et al. 2018), indepth analysis of entrepreneurship research (Vuong et al. 2020b, d), and investigations of international publishing in Vietnam from various perspectives (Vuong et al. 2020a, c, e).

Regarding gender bias in scientific publications, Ho et al. (2017a) found that the gender difference in academic publications is negligible by using a small dataset of 412 Vietnamese authors and their works in the Scopus database. Moreover, the productivity of researchers was found to be positively correlated with the number of articles in which they are corresponding authors and the seniority of the authors. Further analysis of researchers' contribution to a publication also indicated the importance of seniority in the productivity of Vietnamese researchers as well as the neglectable gender difference (Vuong et al. 2018). The study further emphasized the crucial contribution of 'first authorship' in improving the research output.

In terms of collaboration, Ho et al. (2017b) found that 33 out of 412 Vietnamese scientists in the dataset never collaborated with other researchers in the 2008-2017 period. Notably, at least $65 \%$ of Vietnamese scientists had collaborated with a foreign author once in their career. However, the international collaboration did not boost the total output of Vietnamese scientists by much. The collaboration network of Vietnamese scientists was sparse with a high level of clustering coefficient, which indicates how likely research (a node) in the network tends to cluster together (Ho et al. 2017b). The analysis of the network of Vietnamese scientists suggested that the social sciences community in Vietnam is still dominated by a few authors who were productive and had good connections (Ho et al. 2017b). Thus, the preliminary network indicated that the social sciences community in Vietnam was still unsustainable in the 2008-2017 period.

After publishing the preliminary results, the project published an article about the structure behind their database, named The Social Sciences and Humanities Peer Awards (SSHPA), for peer-reviewed and further investigation (Vuong et al. 2018). The article published the design, logical architecture, and data collection process of the database. The initial dataset of the database was collected manually by using Word and Excel. Later, a semi-structured database on the website was created to accommodate 
the expansion of the data. In the data article, a sample of 657 Vietnamese researchers and 1289 articles was used for validation. The database is accessible from its website: https://sshpa.com/. Currently, the database contains 4460 articles from 2772 Vietnamese authors. The numbers are continually updated to provide the most comprehensive database of Vietnamese social sciences and humanities' productivity.

Different datasets from the database were extracted to explore different aspects of Vietnamese social sciences and humanities. In late 2019, the book The Vietnamese Social Sciences at a Fork in the Road (Vuong and Tran 2019) provided a comprehensive picture of Vietnamese social sciences and humanities through the lens of scientific publications. A dataset of 2,363 articles produced by 1374 Vietnamese authors was used for in-depth analysis. Moreover, this book's contributors interviewed 28 Vietnamese social scientists about their views on what Vietnam Social Science Humanities (SSH) has accomplished and the remaining challenges (Vuong and Tran 2019).

In 2020, a series of papers that stem from SSHPA data were published. Vuong et al. (2020c) analyzed how affiliations and collaboration affected the productivity of Vietnamese scientists. The study found that researchers at universities had higher productivity than researchers based at research institutions. In other publications, a dataset of 111 articles in the entrepreneurship research was extracted from the SSHPA for a thorough investigation of the discipline (Vuong et al. 2020b, d). Vuong et al. (2020b) suggested a focus on the management side of entrepreneurship, the topics of innovation and creativity or culture are still unexplored territory. In addition, Vietnamese entrepreneurship researchers still focus on practical issues rather than entrepreneurship theories (Vuong et al. 2020d). The most recent works suggested that more Vietnamese authors have been taking the leading role, and there is a shift from international collaboration to domestic collaboration (Vuong et al. 2020e). Interestingly, Vuong et al. (2020b) suggested that Vietnamese authors have been adopting open access publishing, with the number of OA articles increased by four times in the 2008-2019 period.

In $\mathrm{SSH}$, the bibliometric data were mainly used to look at the comprehensive picture of the field. Larger datasets from the Web of Science or Scopus are popular for Vietnamese researchers to investigate certain topics such as HIV research (Tran et al. 2019a), innovation research (Le et al. 2019), education (Hallinger and Nguyen 2020), depression among university students in East Asia (Nguyen et al. 2020b), social entrepreneurship (Phan et al. 2020), and non-biomedical modalities (Nguyen 2019). However, no studies have examined the field of development economics. As such, in this study, we deploy the biblometric analysis to answer the following research questions:

RQ1 What are the development patterns of the total output, number of authors, and scientific collaboration in the Vietnamese development economics research in the 2008-2020 period?

RQ2 What are the characteristics and qualities of publishers for Vietnamese development economics research during the 2008-2020 period?

RQ3 What are Vietnamese development economics research trends and interests during the 2008-2020 period? 


\section{Data and methodology}

\subsection{Data source}

The study used The Social Sciences and Humanities Peer Awards (SSHPA) database to collect Vietnamese development economics research data. SSHPA is an open database recording the scientific productivity of Vietnamese social scientists and humanities researchers. A scientific publication is eligible to be included in SSHPA when they are indexed in (1) Web of Science Core Collection database, (2) Scopus database, or (3) fit the criteria for international publications issued by NAFOSTED. For criterion No.3, a list of scientific journals was issued by the NAFOSTED Board of Trustees in 2019 (NAFOSTED 2019), facilitating the searching of high-quality journals published in languages other than English.

Web of Science (WoS) and Scopus are two of the largest scientific databases in the world. However, when it comes to a specific country, they face several obstacles. Firstly, the speed of data updates is slow. Secondly, the records could be defective due to both external and internal factors. Externally, researchers can use multiple versions of their names throughout their careers. Internally, to deal with big data, Scopus and WoS have to use artificial intelligence (AI) to accelerate the process. However, the AI can automatically assign one person with multiple profiles due to the arbitrariness of how they input their names.

Thus, SSHPA was created to combine the best data of these three sources and address social sciences and humanities issues in Vietnam. The database records official scientific publications that have been produced by Vietnamese researchers from 2008 until now. A researcher is eligible when two out of the three following criteria are satisfied:

- The researcher has Vietnamese nationality.

- The researcher is affiliated with a Vietnamese university or research institution.

- The researcher has used data from Vietnam or directly contributed to Vietnam.

When the criteria for researchers and publications are met, a publication, such as a journal article or book, and its authors are recorded into the database. Affiliations, journals, publishers are subsequently collected to provide a thorough record. Due to its flexibility and thoroughness in organizing the data, the SSHPA database was chosen to investigate the development economics research in Vietnam. The following items comprise the data in the SSHPA database:

- Author Researchers whose scientific publications are in the SSHPA database. Based on the characteristics of the researchers in the article, we have two subsets of the author:

- Publisher The organization that published journals, books, edited books, or conference proceedings

- Source The publication where an article was published, which includes journals, books, edited books, or conference proceedings

- Articles The scientific articles published in a source, which can be journal articles, book chapters, or conference papers. A subset of Articles includes Internationally collaborated publications, which are scientific publications in the SSHPA database with at least one author who is not Vietnamese. 
- JIF The annual Journal Impact Factor of a scientific journal indexed in Web of Science Core Collection.

\subsection{Methodology}

\subsubsection{Search strategy}

Based on the literature review, an initial set of keywords was formulated. After we consulted with 2 Vietnamese experts in the field of Development Economics (whose works are also included in the dataset), the set of keywords was revised. Finally, the following set of keywords was used for conducting data collection (see Table 1). As demonstrated in the table, the keywords are generated from 4 categories: Economic Development, Development Measurement, International Trade, and Aid-Debt. The groups are chosen following the literature review and expanded to yield as many relevant publications as possible.

The main goal of the study is to provide a comprehensive picture of economic development research in Vietnam. Thus, keywords were chosen to create the most representative and inclusive dataset. To the best of our knowledge, there has been no similar work done in Vietnam. As our goal is to get as many publications as possible, we used as many keywords as possible to search for relevant literature.

\subsubsection{Data collection}

Using the final set of keywords, we searched for scientific publications in the SSHPA database from 2008 until 2020 (As of August 18, 2020). To ensure a transparent reporting of the data collection process, we follow the PRISMA 2020 guideline for systematic review (Page et al. 2021). We first identified inclusion criteria, then narrowed down the qualified publications through titles and abstracts examination. Based on the PRISMA 2020 guideline, we provided a flow diagram to visualize the reviewing process (see Fig. 1).

The first round of results came up with 943 articles. Then, the author manually read the abstract to identify the most related articles. The second round of filtering resulted in 573 eligible articles. In addition to the SSHPA data, further information that is specific to development economics research was also collected (See Table 2).

\subsubsection{Data analysis}

The study used bibliometrics to explore the landscape of development economics research in Vietnam. A bibliometric method is a useful tool in analyzing the outcomes of research papers and summarizing the development of research disciplines (Mulet-Forteza et al. 2019). This method is highly appropriate with the SSHPA database, which is capable of generating the visualization of network data of the Vietnamese researchers (Vuong et al. 2018). Utilizing the bibliometric approach, we have identified multiple characteristic sets of the dataset, notably targeting journals_-authors' qualities and research fields. 


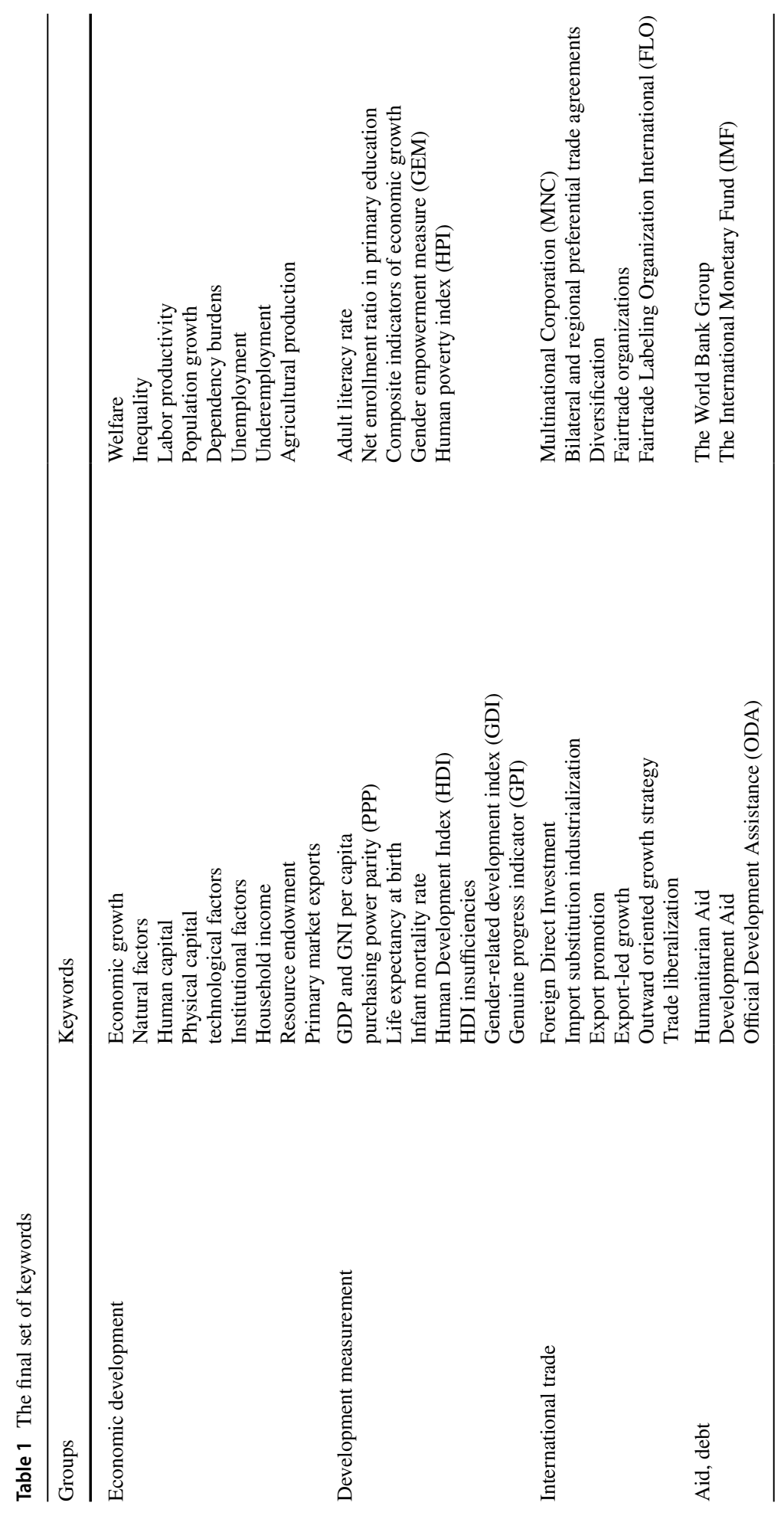


Identification of studies via databases and registers

Records identified through keywords search from titles and abstracts in SSHPA database: $(n=943)$

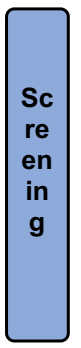

Records screened $(n=943)$

Records excluded from, in-depth abstracts and full-text examination $(n=370)$

Reports included for eligibility from in-depth abstract and fulltext examination $(n=573)$

Studies included in bibliometric analysis

$(\mathrm{n}=573)$

Fig. 1 PRISMA diagram describing the collection of data on SSHPA database

\section{Results}

Based on the keywords, 573 articles were collected in the 2008-2020 period (as of August 18, 2020). 573 articles were written by 1001 authors (684 Vietnamese authors), published in 317 sources from 68 publishers. According to Google Scholar, 573 articles were cited 11,085 times. In this section, we will examine the characteristics of the 573 articles based on the research questions. In detail, Sect. 4.1 corresponds to RQ1, Sects. 4.2 and 4.3 correspondes to RQ2, and Sect. 4.4 correpondes to RQ3.

\subsection{Overview}

\subsubsection{Articles}

Figure 2 presents the number of articles in the field. The number of articles had been rising steadily, with the peak in 2019 (115 articles). However, 2020 needs only 14 more to surpass 2019. As the annual growth rate of the examined period is around $23 \%$, we expect 


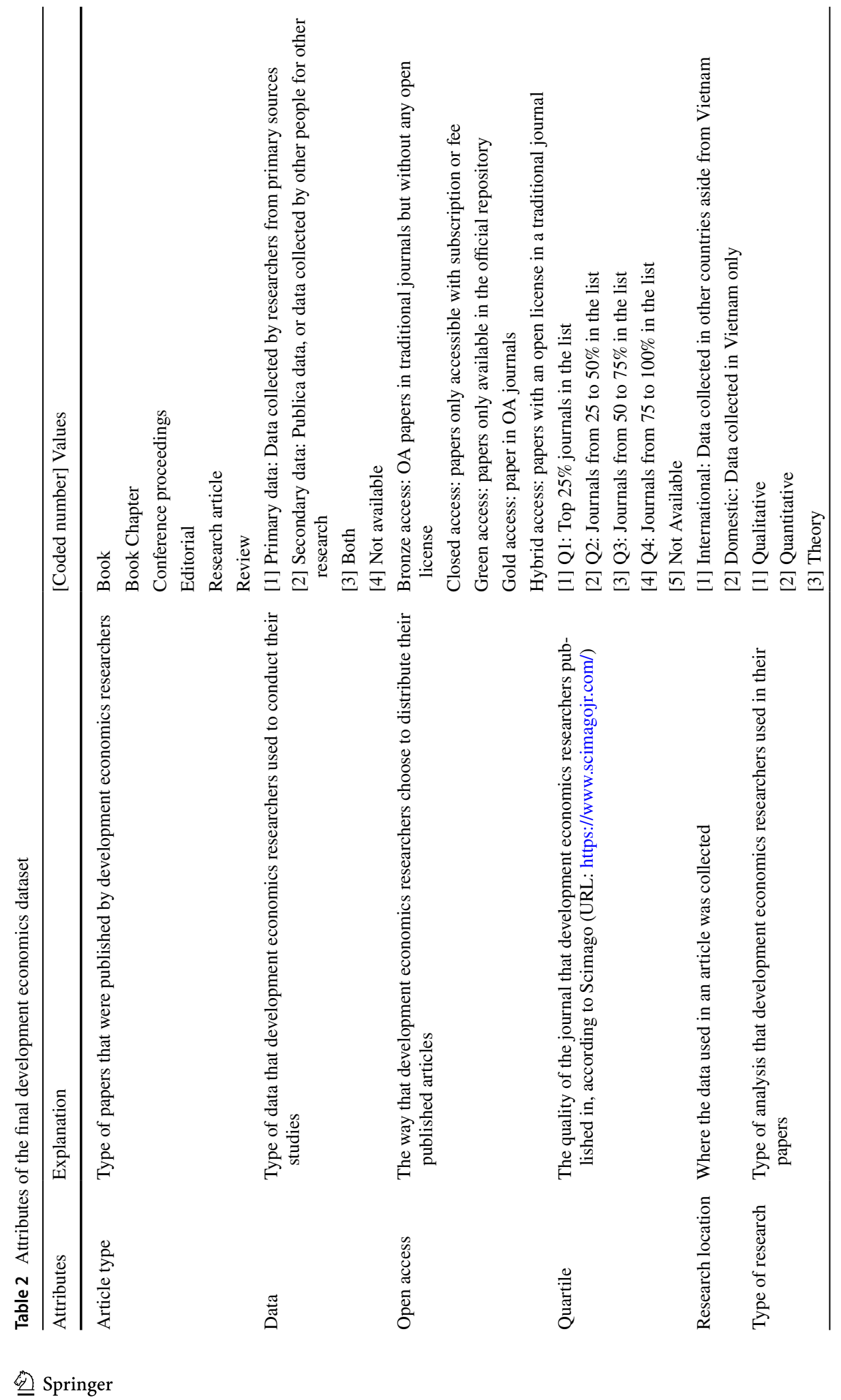




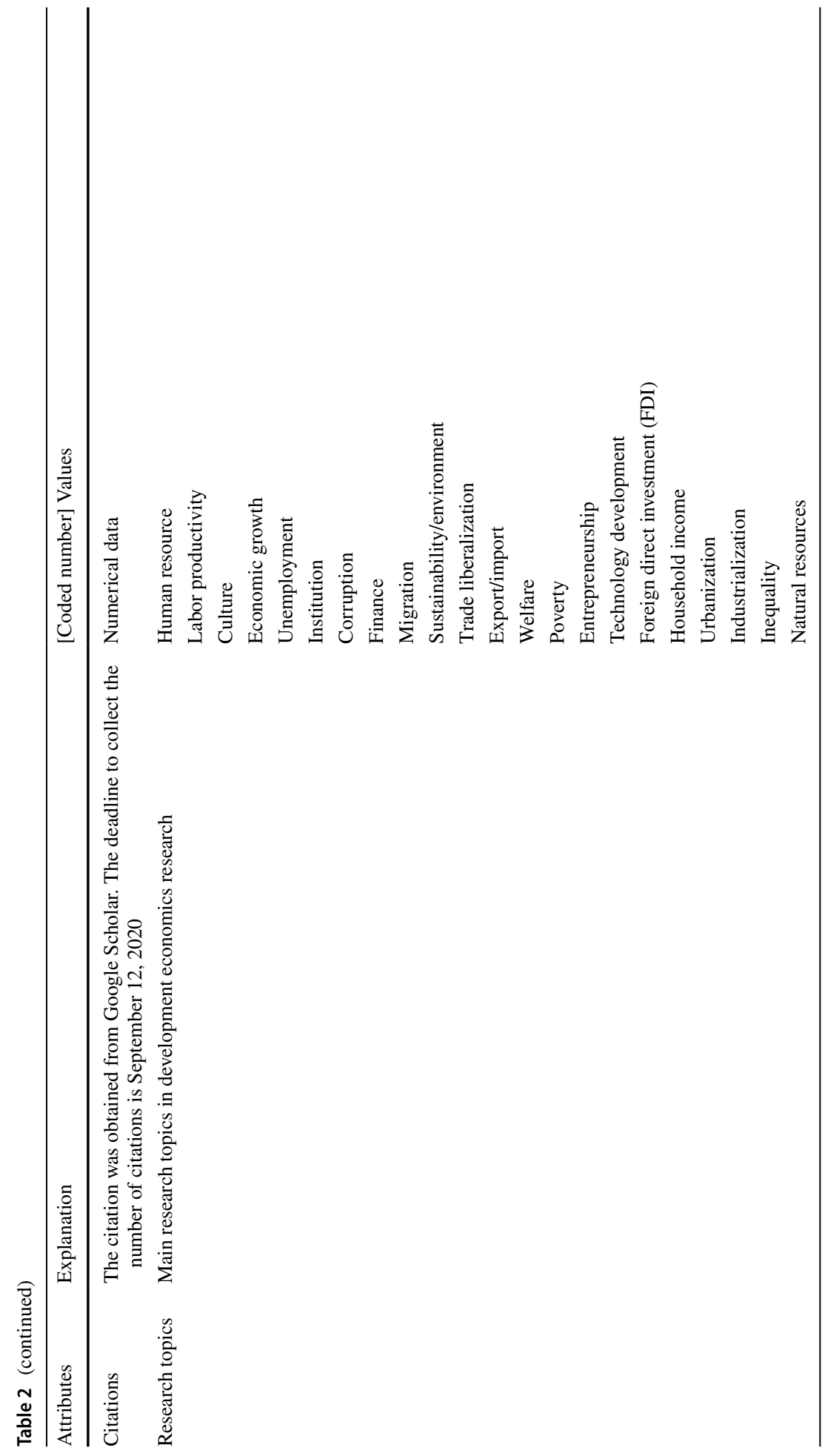


the number of articles in 2020 will surpass 2019 , and this trend is likely to continue in the future.

Most development economics research studies are the original research articles, which occupy around $91.9 \%$ of the total publications (see Fig. 3). Meanwhile, the number of other types of publications is low. The number reflected the focus on publishing original research and the high capacity to publish by development economics researchers. It is noticeable that other types of publications are lacking, especially book, editorial, and reviews.

Figure 4 presented a high number of quantitative research (462 articles). The number reflected the dominance of quantitative methods in the field. Meanwhile, a qualitative or theoretical study is still new territory for Vietnamese development economics researchers.

The high number of quantitative studies is possibly due to the abundance of secondary data (see Fig. 5). We found 377 out of 573 articles used secondary data, not to mention 18 studies used both types of data. In Vietnam, the availability of the Household Living Standards Survey, which is conducted every 2 years by the General Statistical Office, has created a reliable dataset for researchers (World Bank 2020).

Figure 6 shows that the research data were mainly collected in Vietnam. Only 14\% of the articles used international data.

\subsubsection{Authors}

Figure 7 presents the number of authors who published in development economics from 2008 until 2020. The number steadily rose throughout the period, with a peak in 2019 (282 authors). However, it is noteworthy that the number for 2020 was only until August 18, 2020. With 241 authors in 2020, the number of authors exceeds that of 2019.

A look at the dataset identified 56 out of 684 Vietnamese researchers in the top 5\% of the highest productivity in development economics in the examined period. The top 5\% of authors had 290 articles, representing $50.61 \%$ of the total productivity. In Table 3, the top 10 authors are presented.

Notably, even within the top 10 authors, the disparity between the top half and the bottom half is significant. The top 5 authors' total output was twice the total number of the bottom half of authors. The leading researcher had around 5.6 times more articles than the last researchers in the top 10 . The following table indicates the most notable publications of the top $5 \%$ of authors in this field.

\subsubsection{Scientific collaboration}

Figure 8 presents the development of the co-author's network of Vietnam's development economics research. In 2008, the number of Vietnamese authors was insignificant (Blue and pink nodes), and the collaboration was mainly with foreigners (Orange node). Eleven years later, the network of Vietnamese authors in development economics research had matured with many research teams. In the center of 2019's network, we can see at least 2-3 large teams, consisting mostly of Vietnamese authors. The network suggested that Vietnamese researchers had become more independent. Moreover, large research teams with Vietnamese authors as the leader has become more common.

While Vietnamese authors had grown to be more independent, international collaboration was still a major contribution to the scientific productivity of Vietnamese researchers 


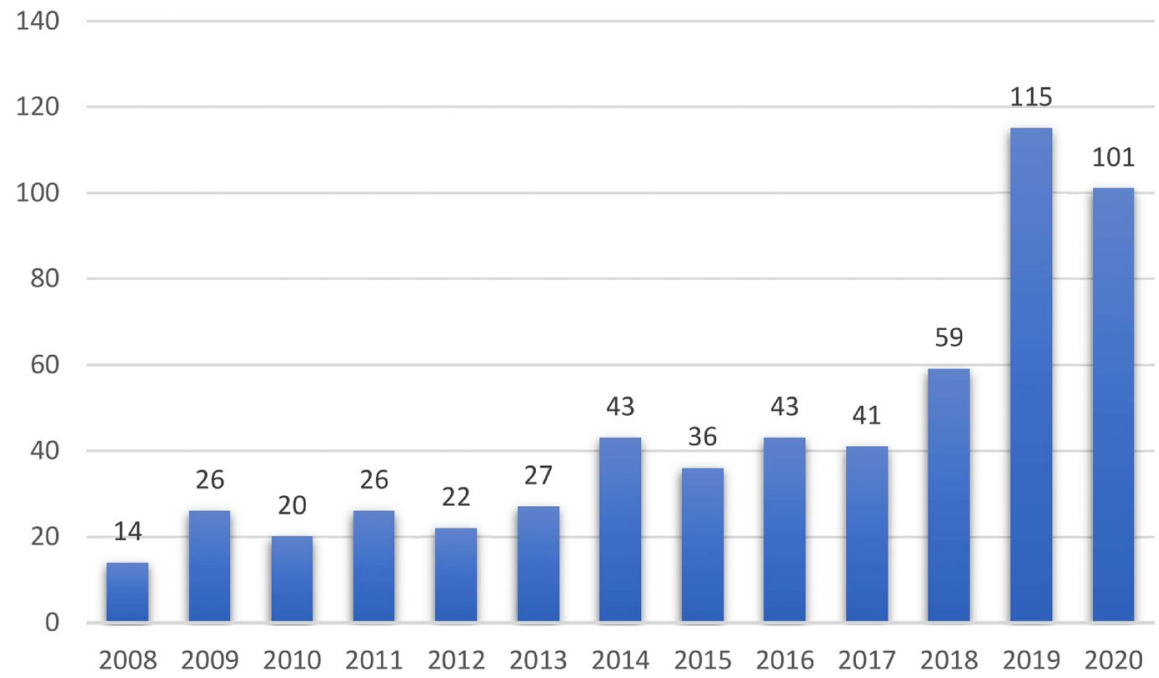

Fig. 2 The total number of articles in the development economics in the 2008-2020 period

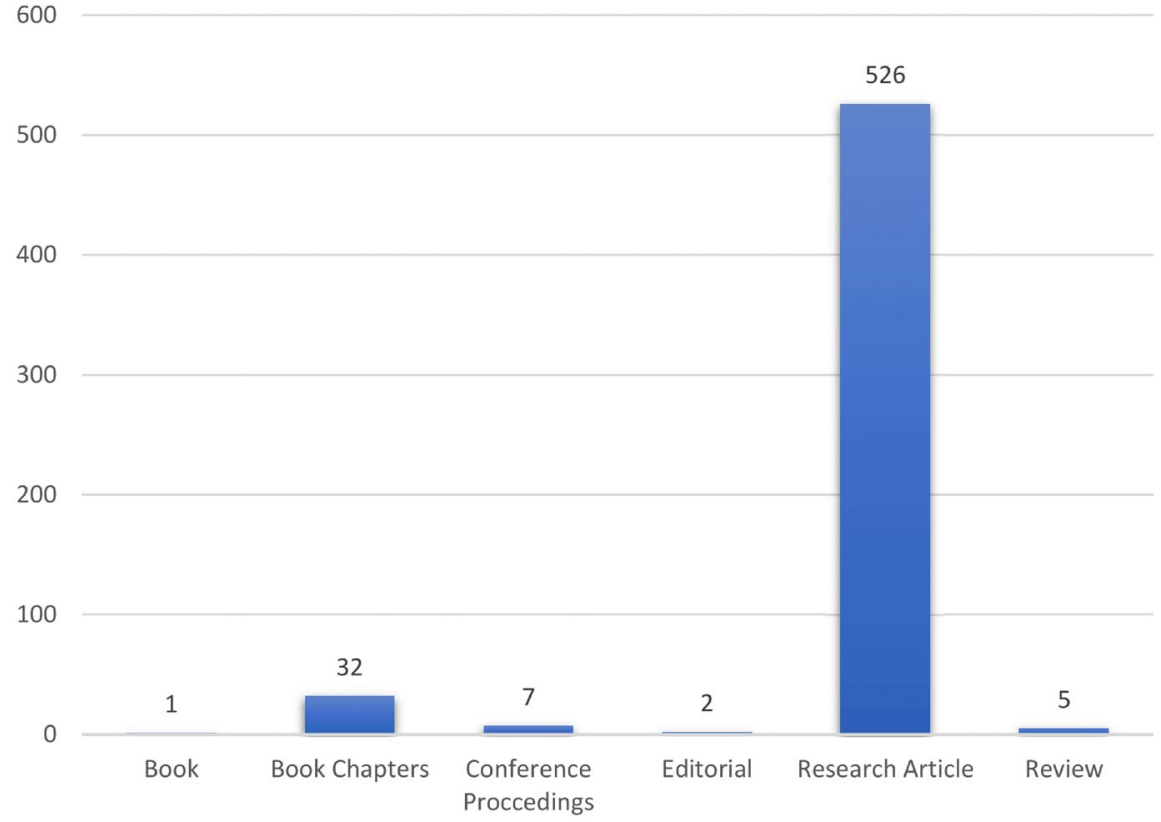

Fig. 3 Number of articles by article type

(Fig. 9). In 2008, there were only a few connections to other countries, such as the United States or Europe. As the total output of Vietnam grew, the map of international collaboration also grew considerably in 2014 and 2019. 
Fig. 4 Number of articles by type of research

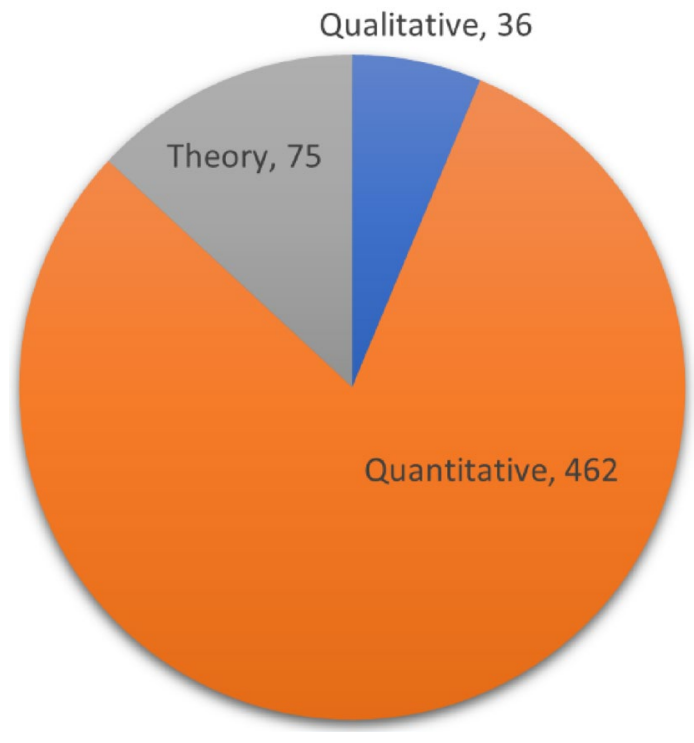

Fig. 5 Number of articles by data type

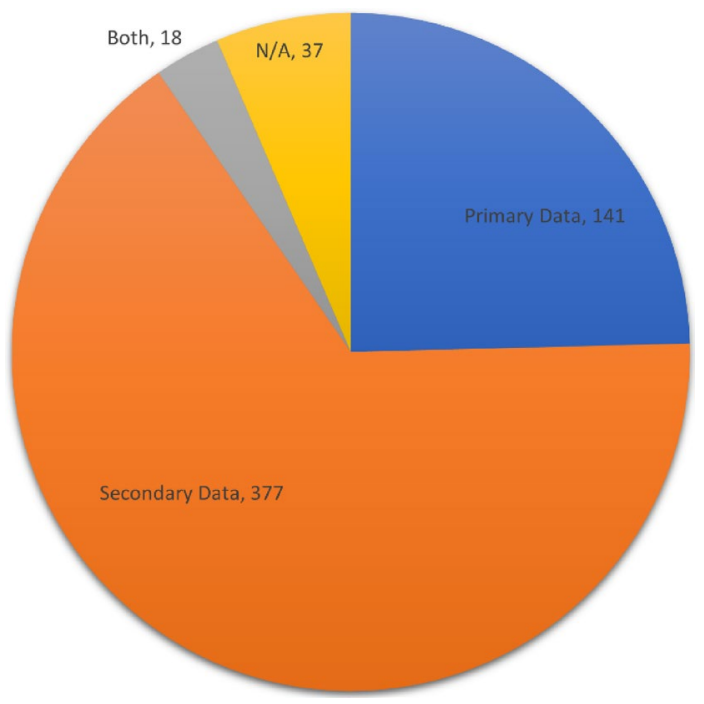

In 2014 and 2019, the international collaboration was extended to various locations in Europe and Australia. Other cities and provinces in Vietnam also collaborated with international regions actively.

In general, independent Vietnamese authors and international collaborations boosted the total output of development economics research in Vietnam in the 2008-2019 period. 


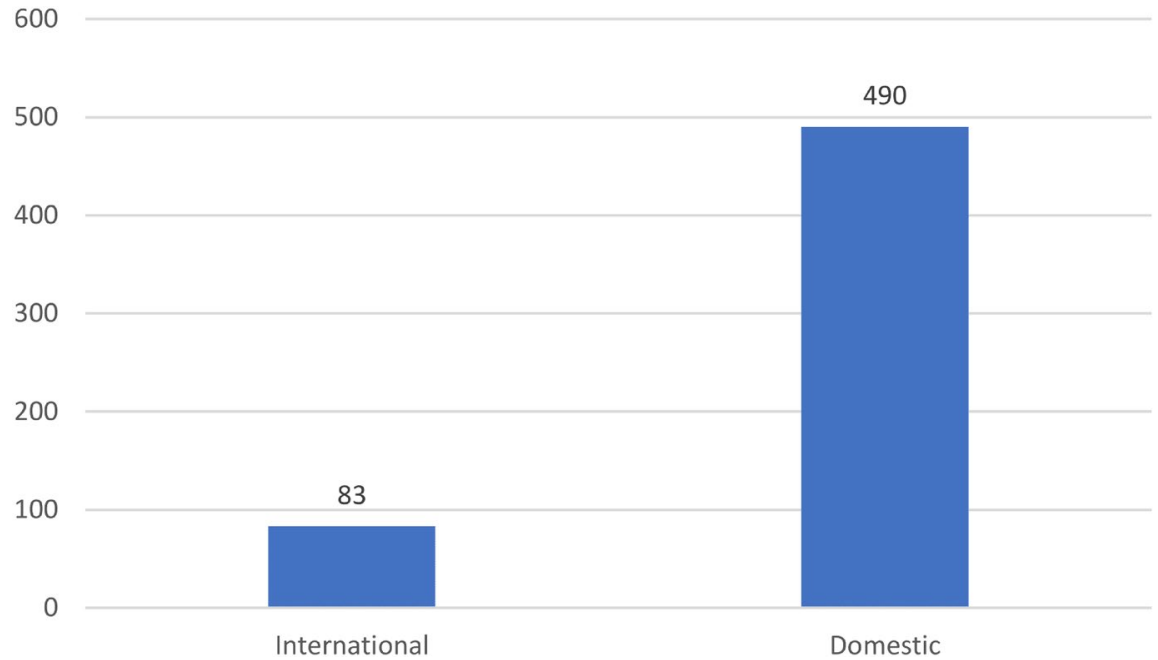

Fig. 6 Number of articles by Data Source (where the research data were collected)

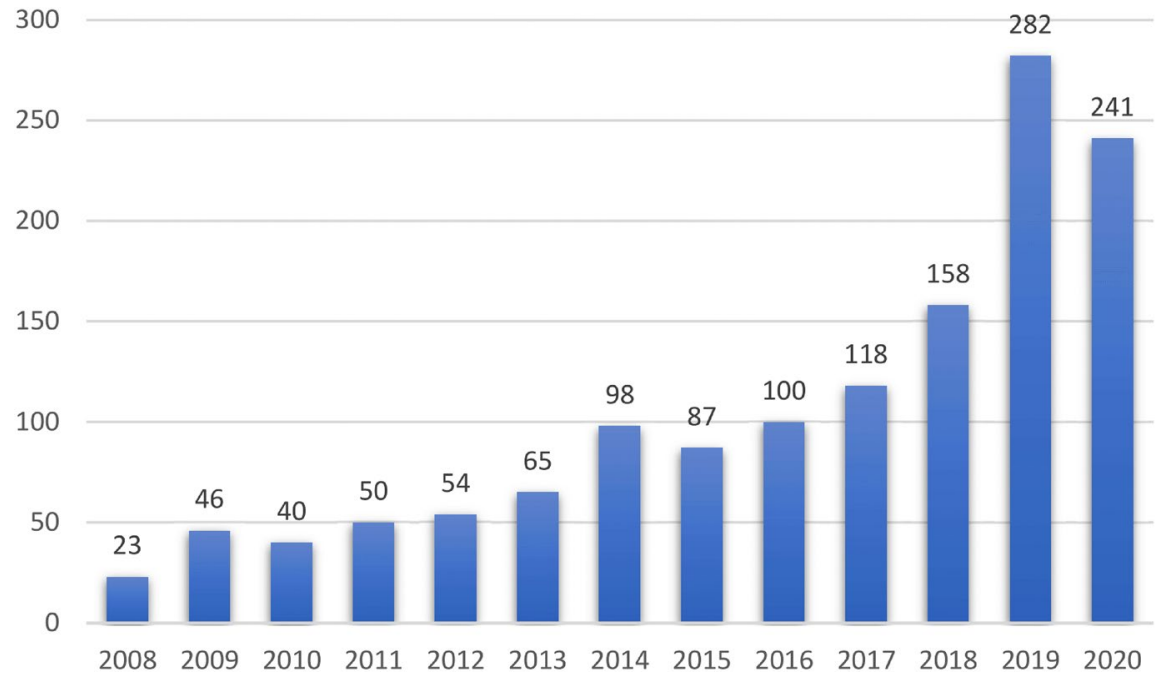

Fig. 7 Number of authors published development economics papers in the 2008-2020 period

\subsection{Publishing}

Tables 4 and 5 provided the lists of the top 15 journals and publishers that Vietnamese authors published the most.

In the top 15 journals, the quality of the journals, which is represented by Scimago's Quartile, is relatively high. There were four Q1 journals in all sections and three journals with both Q1 and Q2 sections. Moreover, Q2 journals also occupied 33\% of the list. In the top 5 journals, the majority were Q1 and Q2 journals, with highly respected journals in the 
field such as World Development (established in 1975) or Journal of Development Studies (established in 1964).

The top 15 publishers with the highest Vietnamese publications (see Table 5) included well-known names in the top 5 such as Taylor \& Francis, Elsevier, Springer, or Wiley. 11 out of 15 publishers were traditional ones with history and a large portfolio of scientific journals. Meanwhile, there were some new names on the list, suggesting that Vietnamese researchers have constantly explored new publishing venues.

As Table 5 suggested, most publishers were traditional ones; thus, the number of closed access articles also accounted for the majority (around 55\% of the total, see Fig. 10). Meanwhile, the open-access article in all forms occupied $43 \%$ of the total. Notably, the number of fully open access was relatively high: 161 articles. The number of green open access articles suggested that some Vietnamese authors have supported the OA movement and made their articles available on the repository.

\subsection{Quality}

Figure 11 shows the distribution of quartiles among the examined articles. Surprisingly, many articles belong to Q1 and Q2 categories (around 59\% of the total). Presumably, these two categories are higher-quality journals. The results suggest that the quality of research on economic development issues in Vietnam has reached a relatively sufficient level for Q1 and Q2 journals' standards. In addition, the data can also signify the interest of the international research community in Vietnam's development issues, as a total of 339 papers are published in Q1-Q2 journals.

However, the number of citations is a different story. The most cited article published in 2010 had 311 citations (Anwar and Nguyen 2010). Meanwhile, the majority of articles only had from 0 to 10 citations (see Fig. 12). In addition, the raw number of citations did not account for when the article was published. Thus, we created a new variable by dividing the citations that an article had for the period since its publications. In this way, the most cited article was published in 2014, as it took 6 years to attain 266 citations (Huynh 2014).

Table 3 Top 10 authors by the number of publications

\begin{tabular}{lll}
\hline Authors No & $\begin{array}{l}\text { Number of } \\
\text { article }\end{array}$ & Notable publications \\
\hline 1 & 45 & Mont and Nguyen (2011), Nguyen and Pham (2018) and Nguyen (2011) \\
2 & 23 & Tran et al. (2018b), Tran et al. (2015), Tran et al. (2018a) \\
3 & 16 & Giang and Pfau (2009) and Nguyen et al. (2020a) \\
4 & 13 & Tran et al. (2018b), Tran et al. (2015) and Tran et al. (2018a) \\
5 & 13 & Dinh et al. (2019) and Vo et al. (2019) \\
6 & 12 & Giang et al. (2016) and Hoang et al. (2016) \\
7 & 11 & Nguyen et al. (2019) and Tran et al. (2019b) \\
8 & 11 & Ha and Ngoc (2020), Vuong (2019), Vuong et al. (2020a; b, c, d) and \\
9 & 9 & Vuong and Nancy (2014) \\
10 & 8 & Bui (2020) and Ha and Ngoc (2020) \\
\hline
\end{tabular}




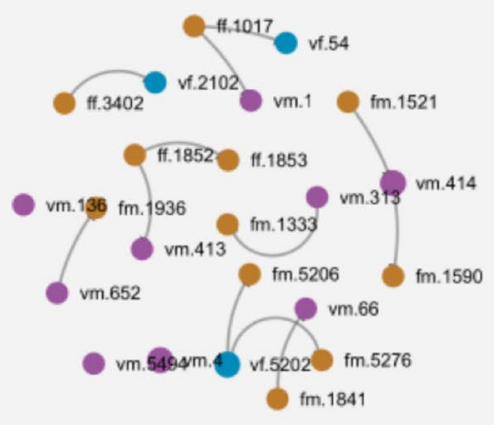

(a) 2008

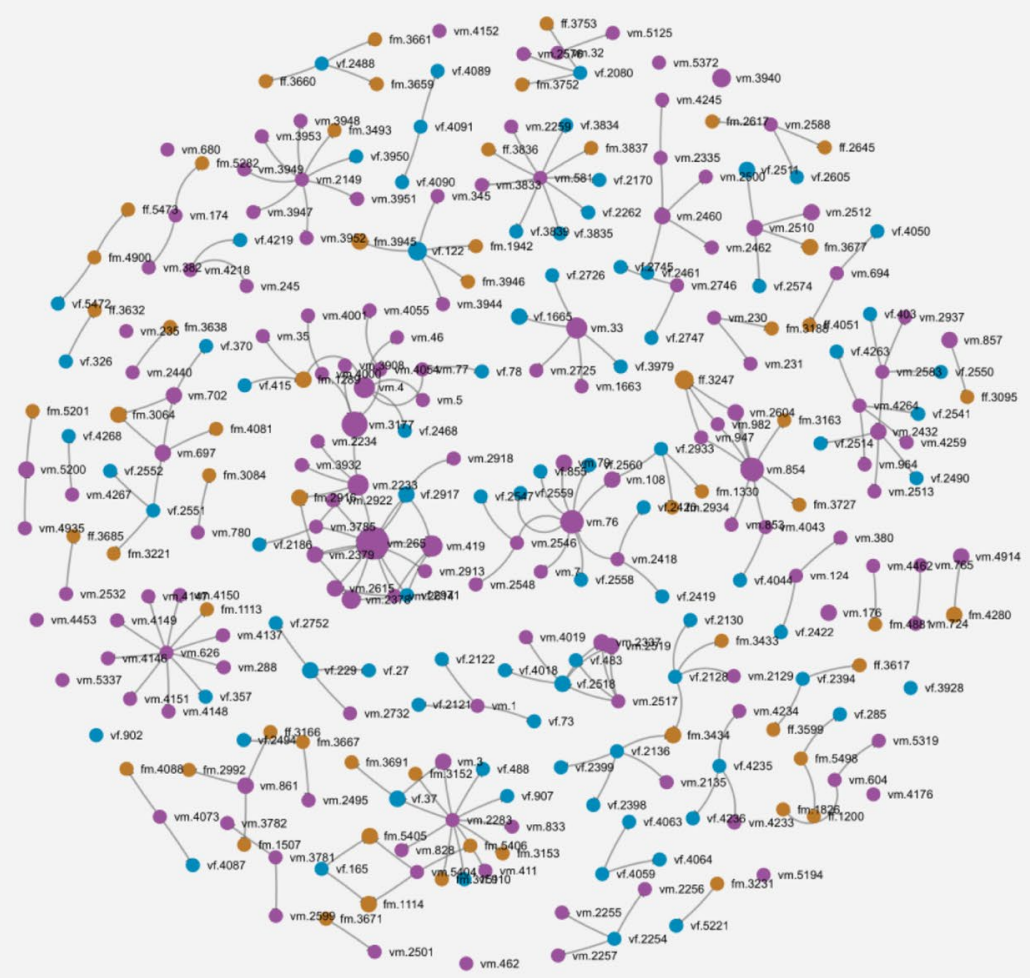

(b) 2019

Fig. 8 The international collaboration of Vietnamese development economics researchers in a 2008 and b 2019 (2020 was excluded due to incomplete data). Note: The Blue node represents a Vietnamese female author; the Pink node a Vietnamese male author; the Orange node a foreign author 

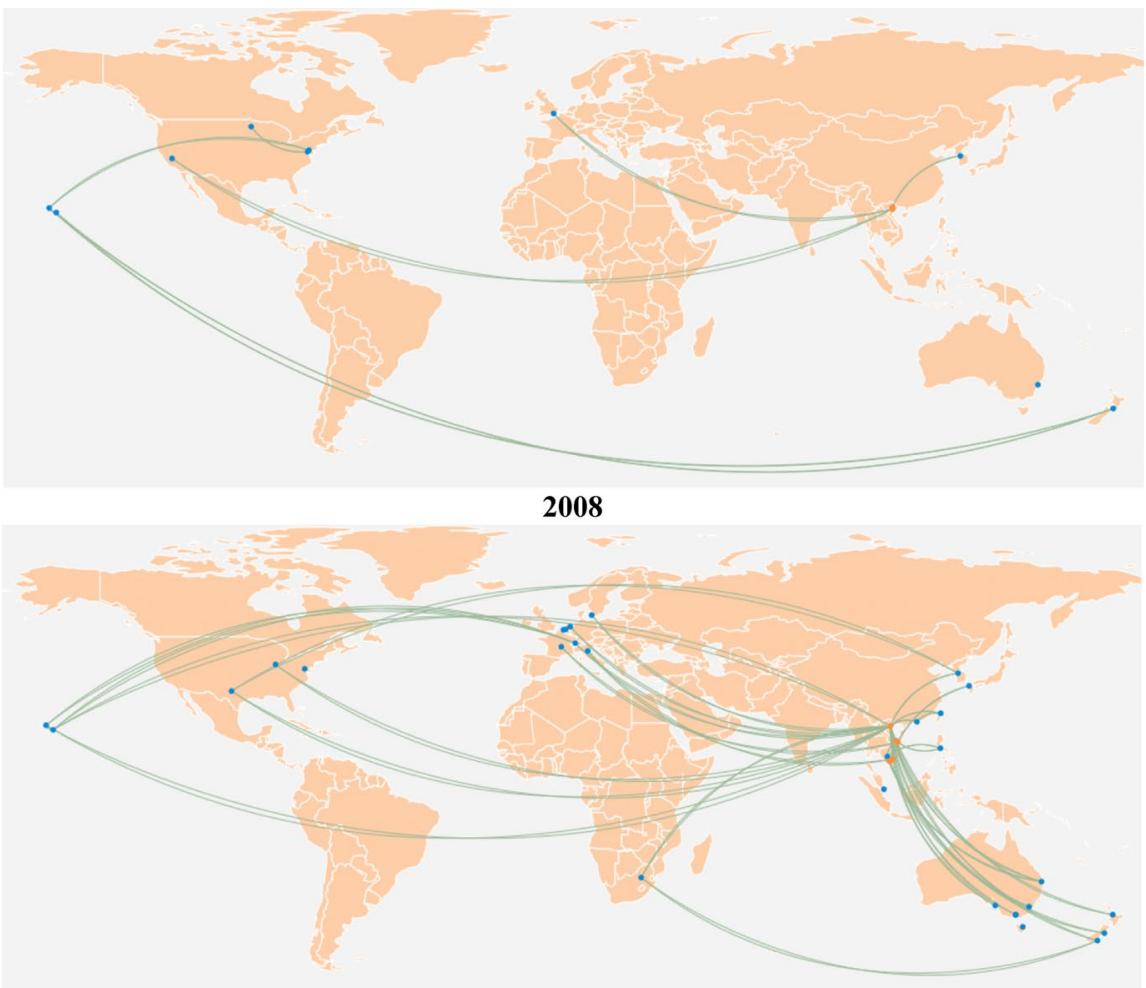

2014

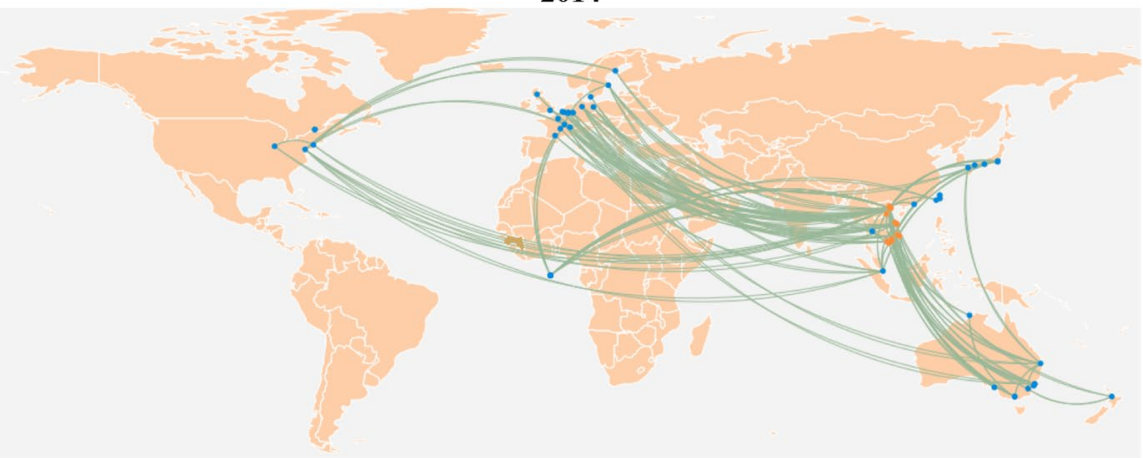

2019

Fig. 9 The international collaboration of Vietnamese development economics researchers in 2008, 2014, and 2019 (2020 was not chosen due to incomplete data)

\section{Research topics}

The field of development economics is highly interdisciplinary. The dendrogram in Fig. 13 showed that 18 big fields in SSH have contributed to the development economics literature in Vietnam. Indeed, Economics contributed the most articles, which was 
Table 4 Top 15 journals with the most publications

\begin{tabular}{lll}
\hline Journals & Article & $\begin{array}{l}\text { Quartile (as of } \\
\text { October 27, } \\
2020)\end{array}$ \\
\hline Sustainability & 20 & Q2 \\
Journal of the Asia Pacific Economy & 13 & Q2 \\
Journal of Development Studies & 13 & Q1 \\
Journal of Asian Finance, Economics and Business & 13 & Q1 \\
World Development & 11 & $\mathrm{Q} 1 / \mathrm{Q} 2$ \\
Social Indicators Research & 9 & $\mathrm{~N} / \mathrm{A}$ \\
Journal of Risk and Financial Management & 8 & $\mathrm{Q} 2$ \\
Applied Economics & 8 & $\mathrm{Q} 2$ \\
Management Science Letters & 7 & $\mathrm{Q} 1$ \\
Energy Policy & 7 & $\mathrm{Q} 2 / \mathrm{Q} 3$ \\
Economies & 7 & $\mathrm{Q} 1 / \mathrm{Q} 2$ \\
Economic Analysis and Policy & 7 & $\mathrm{Q} 2$ \\
Journal of Asian Economics & 6 & $\mathrm{Q} 1$ \\
Global Health Action & 6 & $\mathrm{Q} 1 / \mathrm{Q} 2$ \\
Emerging Markets Finance and Trade & 6 & \\
\hline
\end{tabular}

Table 515 publishers with the highest Vietnamese publications

\begin{tabular}{lc}
\hline Publishers & Articles \\
\hline Taylor \& Francis & 103 \\
Elsevier & 98 \\
Springer & 71 \\
Wiley & 53 \\
MDPI & 43 \\
Emerald & 37 \\
SAGE & 21 \\
Korea Distribution Science Association & 13 \\
Growing Science & 10 \\
World Scientific & 10 \\
Inderscience & 8 \\
Oxford University Press & 8 \\
Canadian Center of Science and Education & 6 \\
Routledge & 6 \\
Cambridge University Press & 5 \\
\hline
\end{tabular}

represented by the size of the largest circle. The following were Sociology, Agriculture, Environment/Sustainability Sciences, Education and Health Care.

Table 6 presents the number of articles according to each research topic in development economics research in Vietnam. It should be noted that one article can be assigned to multiple topics. Thus, the number represents which topics have been discussed or 
mentioned the most in the literature. Based on the number of articles on each topic, we can divide the research topics into three groups:

- The most discussed topics: Household Income, Poverty, Welfare, Institution.

- The heated topics: Inequality, Human Resource, Sustainability/Environment, FDI, Economic Growth, Finance, Export/Import, Labor Productivity.

- The emerging topics: Natural Resources, Trade Liberalization, Entrepreneurship, Migration, Technology Development, Unemployment, Culture, Urbanization, Corruption, Industrialization

The most discussed topics had the highest number of articles on each topic. Figure 14 suggests that the topics are also highly connected. Indeed, poverty, household income, and welfare are interconnected issues that require coordinated efforts to be solved effectively. Meanwhile, institutional issues touch upon almost every aspect of the economy.

The heated topics consisted of topics that are gaining more attention from the researchers in Vietnam (see Fig. 15). These topics are not fundamental issues like the most discussed topics, but they are all very important for Vietnam to achieve a more sustainable economic development. As Vietnam has become more integrated with international trade, Foreign Direct Investment or Export/Import is necessary to navigate its relationship with international partners. Meanwhile, economic development is concerned with inequality, gender, class, or Environmental/Sustainability issues. Finally, managing the country's Human Resources, Labor Productivity, Finance, and especially different aspects of Economics Growth is crucial for maintaining a high level of economic growth while keeping abreast of new problems.

Finally, emerging topics (see Fig. 16) included emerging topics (such as Natural Resources) or niche topics (such as Urbanization). These topics can be traced back to the heated and the most discussed topics. For instance, Natural Resources is an important aspect of Environmental/Sustainability, which garnered more attention as Vietnam

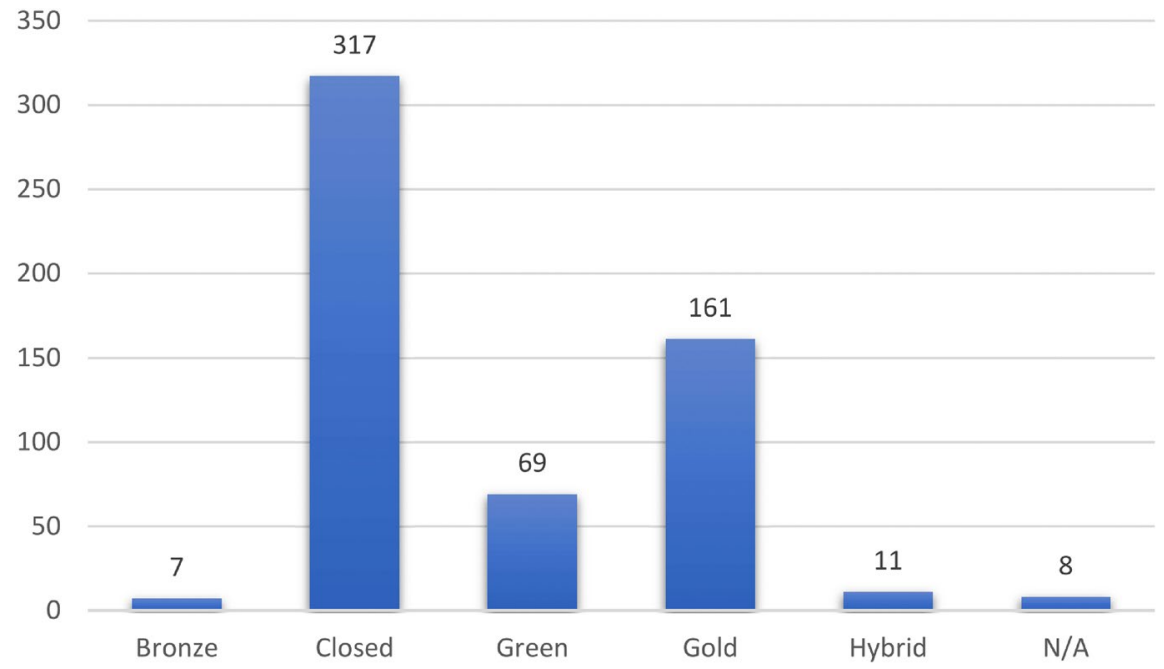

Fig. 10 Number of articles by open access 
Fig. 11 Number of articles by quartile
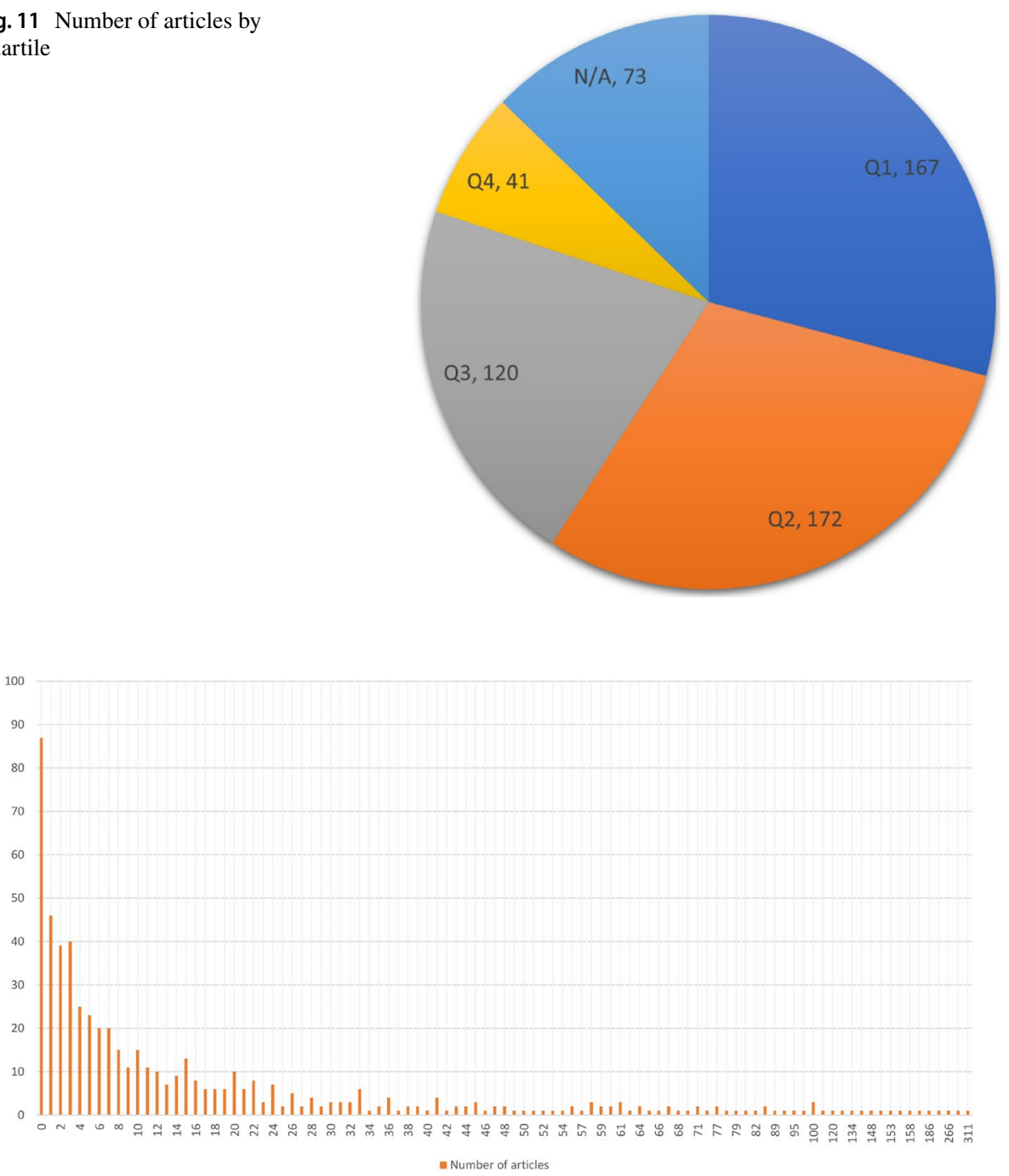

Fig. 12 Distribution of citations by the number of articles

started to feel the adverse consequences of fast economic development in the form of population hyperdensity, environmental contamination, deforestation, etc. Unemployment and Migration can also be discussed in Labor Productivity or Human Resources.

Meanwhile, the Development of Information Communication Technologies can be considered a uniquely 21st-century issue. How technology will contribute to the course of development or how livelihood will change with technology are all new questions. The introduction of new variables such as the Internet, social media, or smartphone presents new and exciting challenges for researchers. In such a drastic change, cultural sustainability is an important anchor for a country like Vietnam to balance between the modernization and traditional way of life. In the future, the study of culture and information communication technologies can 


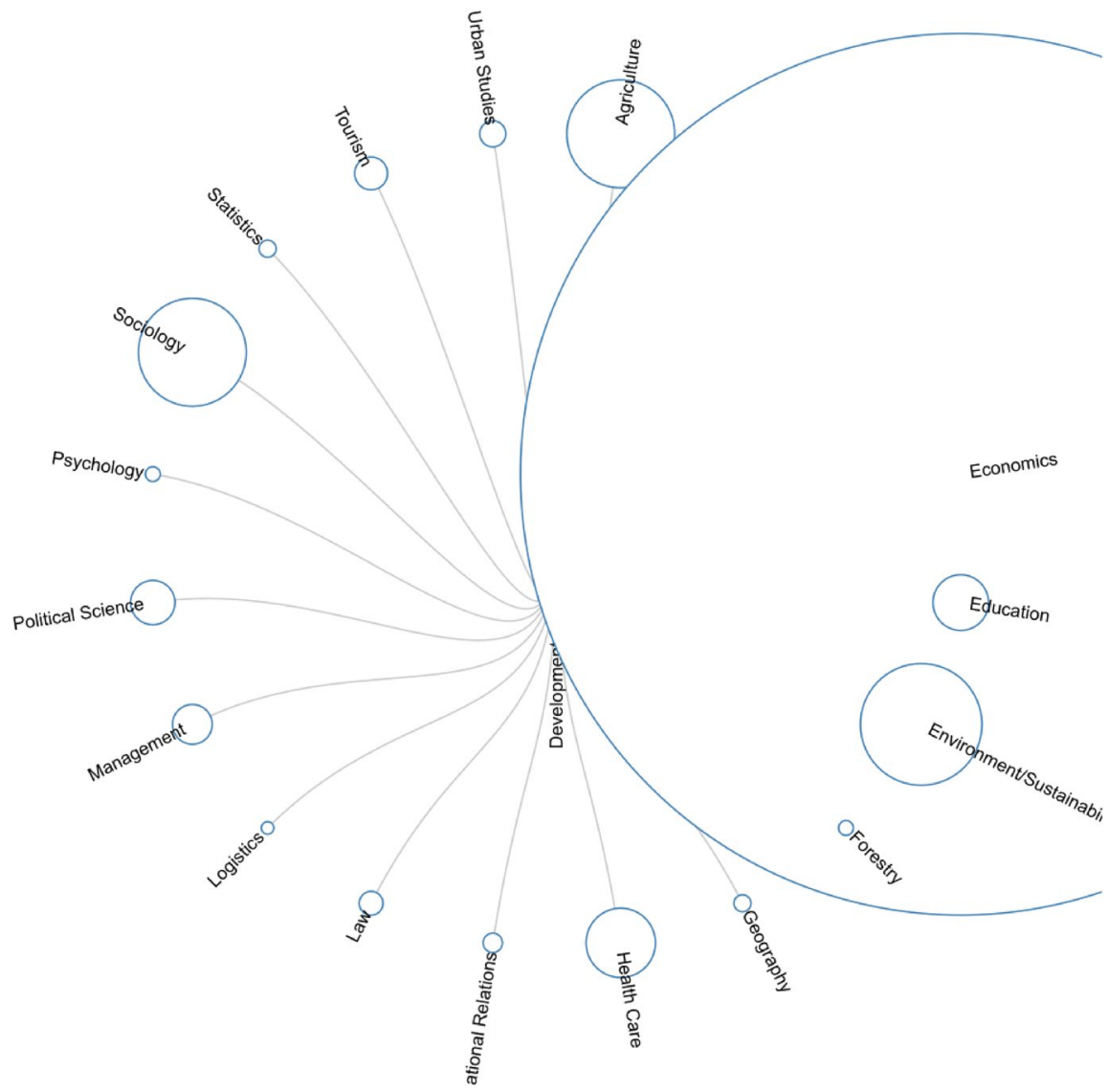

Fig. 13 Dendrogram of development economics research in Vietnam in the 2008-2020 period

go hand-in-hand. The unenthusiastic engagement of development economic researchers to Urbanization, Corruption, and Industrialization issues in Vietnam is thought-provoking and noteworthy, possibly due to the lack of data.

\section{Discussion and conclusion}

Following the development of the economy and science in Vietnam, the scientific productivity of development economics is also rising. Annually, the number of articles experienced a growth rate of around 23\%. In 2020, the total output was 101 articles as of August; thus, we expect an upward trend.

Similarly, authors who contribute to the field are also rising, with an annual growth rate of $26 \%$. The rise of scientific publications resulted from the readiness of data, the ability to produce high-quality quantitative studies, the growth of international collaboration, 
Table 6 Number of articles by research topics

\begin{tabular}{|c|c|c|}
\hline Topic & Articles & Examples \\
\hline Household Income & 170 & Few and Tran (2010) and Nguyen (2014) \\
\hline Poverty & 142 & Nguyen et al. (2015) and Nguyen (2011) \\
\hline Welfare & 129 & Coxhead et al. (2012) and Tran et al. (2018a) \\
\hline Institution & 121 & Giang and Pfau (2009) and Meschi et al. (2016)) \\
\hline Inequality & 96 & Nguyen and Simkin (2017) and Walder and Nguyen (2008) \\
\hline Human Resource & 77 & Mont and Nguyen (2011) and Tran et al. (2018b) \\
\hline Sustainability/Environment & 75 & Christensen and Bach (2015) and Nguyen et al. (2017b) \\
\hline FDI & 70 & Anwar and Nguyen (2011) and Nguyen et al. (2017b) \\
\hline Economic Growth & 62 & Nguyen and Pham (2018) and Nguyen et al. (2017a) \\
\hline Finance & 61 & Dinh et al. (2019) and Thu and Goto (2020) \\
\hline Export/Import & 59 & Hoang et al. (2020) and Pham et al. (2019a) \\
\hline Labor Productivity & 57 & Huy and Nonneman (2016) and Tung (2017) \\
\hline Natural Resources & 50 & Dinh et al. (2017) and Giesecke et al. (2013) \\
\hline Trade Liberalization & 47 & De Silva and Nguyen (2011) and Kikuchi et al. (2018) \\
\hline Entrepreneurship & 45 & Nguyen and Nordman (2018) and Nguyen and Freeman (2009) \\
\hline Migration & 38 & Hoang et al. (2012) and Nguyen and Vu (2018) \\
\hline Technology Development & 29 & Le and Pomfret (2011) and Vuong and Nancy (2014) \\
\hline Unemployment & 24 & Ho et al. (2020a) \\
\hline Culture & 12 & Nguyen et al. (2020a) and Nguyen et al. (2009) \\
\hline Urbanization & 9 & Arouri et al. (2017) and Nguyen and Nguyen (2018) \\
\hline Corruption & 6 & Nguyen et al. (2016) and Truong (2020) \\
\hline Industrialization & 4 & Chau (2018) and Pham et al. (2019b) \\
\hline
\end{tabular}

and especially the dominance of the top $5 \%$ of authors. They occupied $50.61 \%$ of the total output.

Vietnamese development economics researchers have published frequently in upper-tier journals (Q1 and Q2). In the top 15 journals, Q1 and Q2 journals dominated the list with 13 journals. In the top 5, two journals were highly respected in the field.

Finally, development economics is a highly interdisciplinary research field, having contributions from various major social sciences and humanities disciplines. Traditional topics in development economics (poverty, household income, and welfare) were highly interrelated, and institutional discussion was entrenched in all mentioned topics. Analysis of emerging topics suggested that they reasonably reflected Vietnam's most important public concerns, including international trade and investment, sustainability issues such as environment, inequality, and human resources. Emerging topics in development economics included natural resources, technology, and urbanization, which are relatively underresearched. In addition, we predicted the development of information communication technologies as a fertile topic for the twenty-first century.

Moreover, the transition toward open access is also an important aspect that should not be overlooked. There have been strong initiatives toward embracing this trend, most notably, Plan S, which obliges grant-funded researchers to publish their work in open access journals, further affirming the inevitable trend toward open science in most developed scientific countries (Plan 2020). However, the open-access model can often be mistaken as 


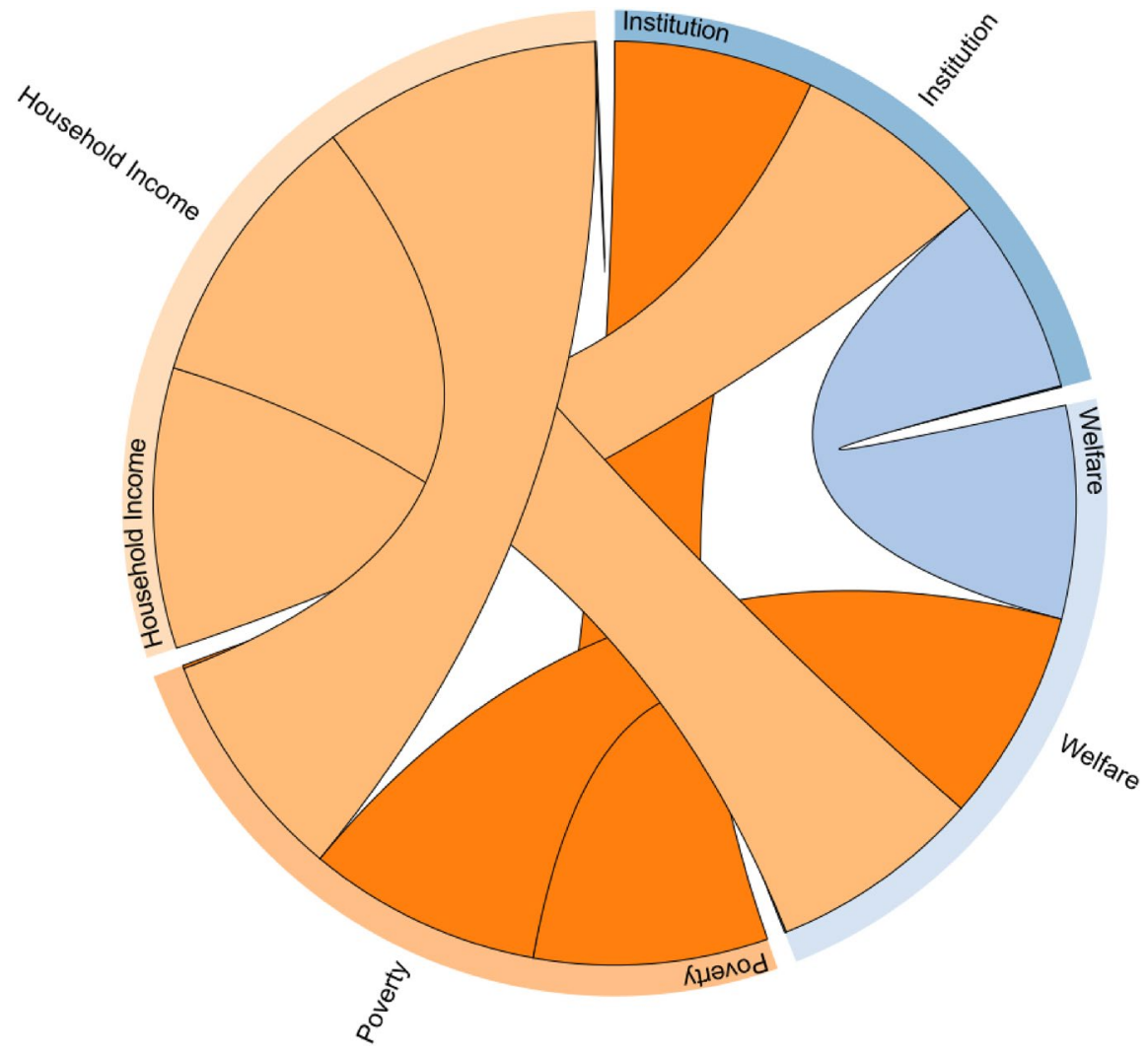

Fig. 14 The connection among the most discussed topics

low quality or a pay-to-publish scheme. Thus, policymakers should review the development of open access journals and provide useful guidelines and supports to manage the cost of science (Vuong 2018).

The promotion of internal capacity is also vital for the field. Currently, Vietnamese authors rely on quantitative research and the availability of secondary data in Vietnam. Nevertheless, researchers should also focus on other scientific innovations as well. For instance, original datasets, innovative methods, or new theories are significant contributions to science that need more encouragement. Policymakers and university leaders can consider various long-term projects that require coherent collaboration in these aspects.

Finally, there are still many under-researched topics in development economics in Vietnam. Principal investigators, research team leaders, and researchers in the field can use the results of this study as an indication for future research direction (Vuong 2020). Regarding research studies utilizing the bibliometric approach in Vietnam, we highly recommend using the SSHPA database for transparency and efficiency in data collection and visualization. As mentioned in the literature review, early bibliometric reviews often involved wellknown databases such as Web of Science or Scopus, which are subscription-based and, 


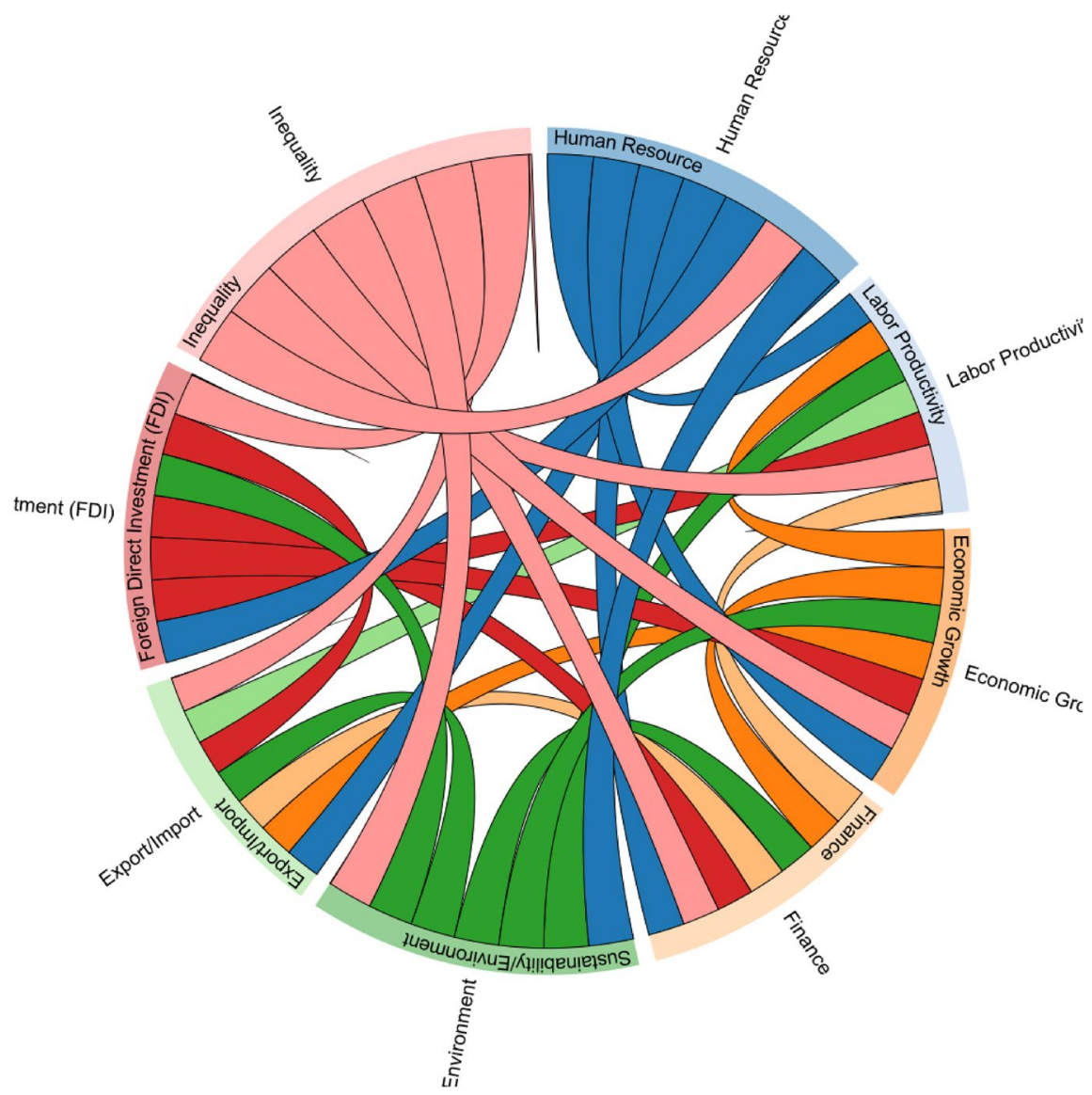

Fig. 15 The connection between the heated topics

thus, expensive for researchers in developing countries such as Vietnam. In such a context, the SSHPA database offers a reliable and cost-efficient tool for Vietnamese researchers to collect tailor-made datasets, which is convenient and time-saving for the research design process. In addition, as the SSHPA database is open to the public and verified by NAFOSTED, we can expect Vietnamese researchers to utilize this database to conduct quality peer-reviewed studies that meet international research standards.

The study is not without limitations. The overview of the development economics research in Vietnam is provided through bibliometric representation. While these statistics are easy to understand, they may not represent the whole picture and overlook more complex issues. Future studies can use more sophisticated methods such as an in-depth review or correlational analysis to explore the associations among various factors, the tendency for open access, and the quality of articles. Besides, in terms of quality, the study used two standard metrics as indicators of quality: journal quartile and number of citations. Other metrics such as journal impact factors can offer different insights. 


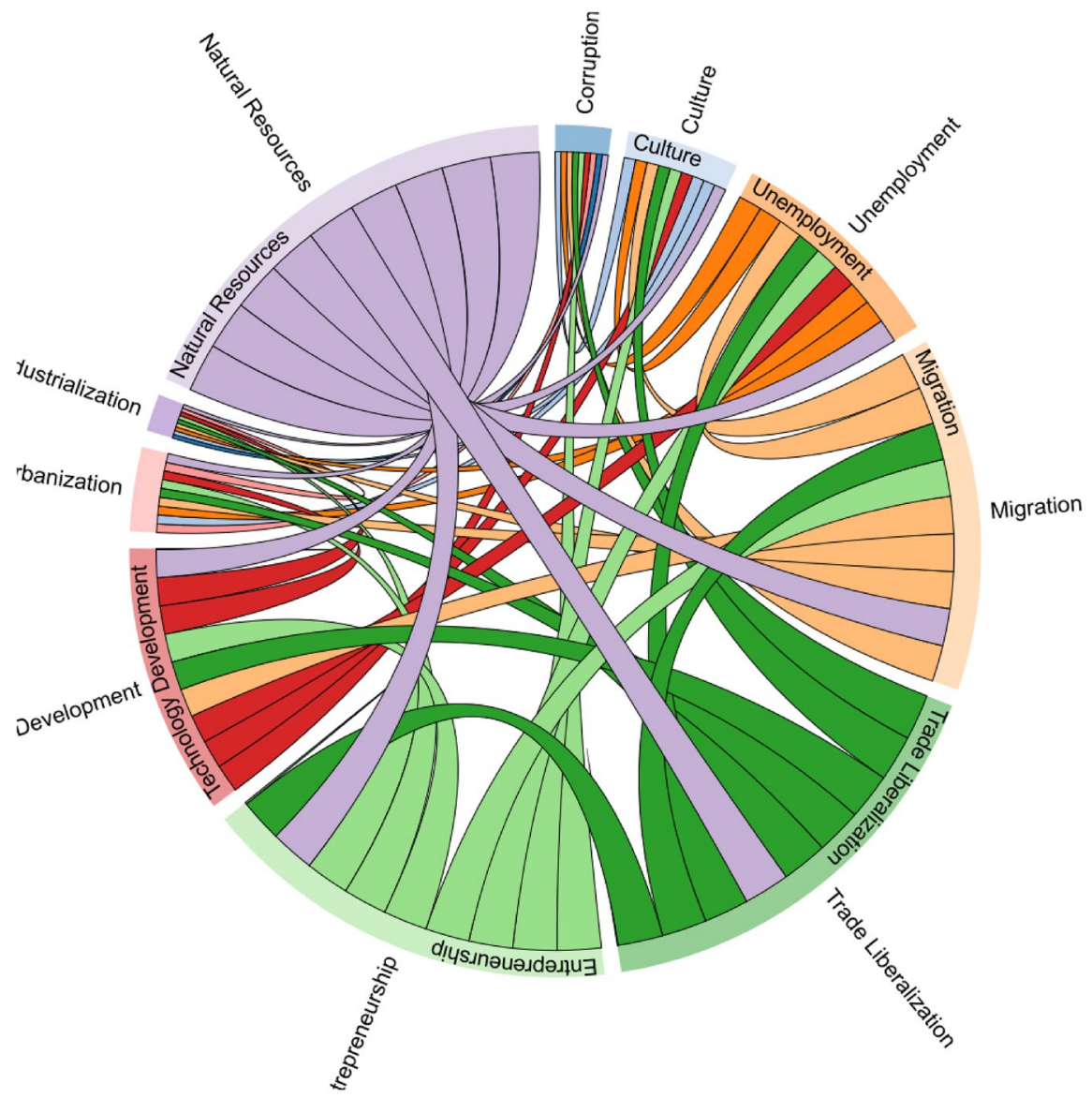

Fig. 16 The connection between the emerging topics

Acknowledgements The authors would like to thank the research staff at the Centre for Interdisciplinary Social Research, Phenikaa University, namely Nguyen To Hong Kong, Nguyen Minh Hoang, La Viet Phuong, Le Tam Tri and Nguyen Thanh Thanh Huyen.

\section{Funding None.}

Data availability The dataset is publicly available on OSF. URL: https://osf.io/32q89/; https://doi.org/10. 17605/OSF.IO/32Q89.

Code availability Examples of code are publicly available on OSF. URL: https://osf.io/32q89/; https://doi. org/10.17605/OSF.IO/32Q89.

\section{Declarations}

Conflict of interest The authors declare that they have no conflict of interest. 


\section{References}

Adams, J., Pendlebury, D., Rogers, G., Szomszor, M.: Global Research Report-South and East Asia. I. f. S. Information (2019)

Anwar, S., Nguyen, L.P.: Foreign direct investment and economic growth in Vietnam. Asia Pac. Bus. Rev. 16(1-2), 183-202 (2010). https://doi.org/10.1080/10438590802511031

Anwar, S., Nguyen, L.P.: Foreign direct investment and trade: the case of Vietnam. Res. Int. Bus. Financ. 25(1), 39-52 (2011). https://doi.org/10.1016/j.ribaf.2010.05.004

Arouri, M., Nguyen, C., Youssef, A.B.: Natural disasters, household welfare, and resilience: evidence from rural Vietnam. World Dev. 70, 59-77 (2015). https://doi.org/10.1016/j.worlddev.2014.12.017

Arouri, M., Ben Youssef, A., Nguyen, C.: Does urbanization reduce rural poverty? Evidence from Vietnam. Econ. Model. 60, 253-270 (2017). https://doi.org/10.1016/j.econmod.2016.09.022

Berenbaum, M.R.: Impact factor impacts on early-career scientist careers. Proc. Natl. Acad. Sci. 116(34), 16659-16662 (2019). https://doi.org/10.1073/pnas.1911911116

Bui, H.N.: Effects of foreign direct investment and quality of informal institution on the size of the shadow economy: application to Vietnam. J. Asian Finance Econ. Bus. 7(5), 73-80 (2020). https://doi.org/10. 13106/jafeb.2020.vol7.no5.073

Chau, L.M.: Actively cautious: industrialization and rural livelihood choices in contemporary northern Vietnam. South East Asia Res. 26(1), 21-37 (2018). https://doi.org/10.1177/0967828x17752415

Chimhowu, A.O., Hulme, D., Munro, L.T.: The 'New' national development planning and global development goals: Processes and partnerships. World Dev. 120, 76-89 (2019). https://doi.org/10.1016/j. worlddev.2019.03.013

Christensen, D., Bach, L.T.: A Danish-Vietnamese partnership for business and technology development in solid waste management. Resour. Conserv. Recycl. 105, 123-133 (2015). https://doi.org/10.1016/j. resconrec.2015.10.019

Coxhead, I., Vu, H.L., Le, D.T.: Global market shocks and poverty in Vietnam: the case of rice. Agric. Econ. 43(5), 575-592 (2012). https://doi.org/10.1111/j.1574-0862.2012.00604.x

De Silva, S.S., Nguyen, T.P.: Striped catfish farming in the Mekong Delta, Vietnam: a tumultuous path to a global success. Rev. Aquac. 3(2), 45-73 (2011). https://doi.org/10.1111/j.1753-5131.2011.01046.x

Dinh, H.H., Nguyen, T.T., Hoang, V.-N., Wilson, C.: Economic incentive and factors affecting tree planting of rural households: Evidence from the Central Highlands of Vietnam. J. for. Econ. 29, 14-24 (2017). https://doi.org/10.1016/j.jfe.2017.08.001

Dinh, T.T.-H., Vo, D.H., Vo, T.A., Nguyen, T.C.: Foreign direct investment and economic growth in the short run and long run: empirical evidence from developing countries. J. Risk Financ. Manag. 12(4), 176 (2019). https://doi.org/10.3390/jrfm12040176

Ellegaard, O., Wallin, J.A.: The bibliometric analysis of scholarly production: How great is the impact? Scientometrics 105(3), 1809-1831 (2015). https://doi.org/10.1007/s11192-015-1645-Z

Elliott, J.H., Turner, T., Clavisi, O., Thomas, J., Higgins, J.P.T., Mavergames, C., Gruen, R.L.: Living systematic reviews: an emerging opportunity to narrow the evidence-practice gap. PLoS Med. 11(2), e1001603 (2014). https://doi.org/10.1371/journal.pmed.1001603

Extance, A.: How AI technology can tame the scientific literature. Nature 561, 273-274 (2018). https://doi. org/10.1038/d41586-018-06617-5

Few, R., Tran, P.G.: Climatic hazards, health risk and response in Vietnam: case studies on social dimensions of vulnerability. Glob. Environ. Change 20(3), 529-538 (2010). https://doi.org/10.1016/j.gloen vcha.2010.02.004

Giang, T.L., Pfau, W.D.: Ageing, poverty and the role of a social pension in Vietnam. Dev. Change 40(2), 333-360 (2009). https://doi.org/10.1111/j.1467-7660.2009.01517.x

Giang, K.B., Oh, J., Kien, V.D., Hoat, L.N., Choi, S., Lee, C.O., Van Minh, H.: Changes and inequalities in early birth registration and childhood care and education in Vietnam: findings from the Multiple Indicator Cluster Surveys, 2006 and 2011. Glob. Health Action 9(1), 29470 (2016). https://doi.org/10. 3402/gha.v9.29470

Giesecke, J.A., Tran, N.H., Corong, E.L., Jaffee, S.: Rice land designation policy in Vietnam and the implications of policy reform for food security and economic welfare. J. Dev. Stud. 49(9), 1202-1218 (2013). https://doi.org/10.1080/00220388.2013.777705

Ha, N.M., Ngoc, B.H.: Revisiting the relationship between energy consumption and economic growth nexus in Vietnam: new evidence by asymmetric ARDL cointegration. Appl. Econ. Lett. 28(12), 978-984 (2020). https://doi.org/10.1080/13504851.2020.1789543

Hallinger, P., Nguyen, V.-T.: Mapping the landscape and structure of research on education for sustainable development: a bibliometric review. Sustainability 12(5), 1947 (2020) 
Heaven, D.: AI peer reviewers unleashed to ease publishing grind. Nature 563, 609-610 (2018). https://doi. org/10.1038/d41586-018-07245-9

Hien, P.D.: A comparative study of research capabilities of East Asian countries and implications for Vietnam. High. Educ. 60(6), 615-625 (2010). https://doi.org/10.1007/s10734-010-9319-5

Ho, M.D.: Scientific publications in Vietnam as seen from Scopus during 1996-2013. Scientometrics 105(1), 83-95 (2015). https://doi.org/10.1007/s11192-015-1655-x

Ho, T.M., Nguyen, H.K.T., Vuong, T.-T., Vuong, Q.-H.: On the sustainability of co-authoring behaviors in Vietnamese social sciences: a preliminary analysis of network data. Sustainability 9(11), 2142 (2017a)

Ho, T.M., Nguyen, H.V., Vuong, T.-T., Dam, Q.-M., Pham, H.-H., Vuong, Q.-H.: Exploring Vietnamese co-authorship patterns in social sciences with basic network measures of 2008-2017 Scopus data. F1000Research (2017b). https://doi.org/10.12688/f1000research.12404.1

Ho, D.B., Nguyen, P.H., Bui, T., Nguyen, H.: Declining protection for Vietnamese agriculture under trade liberalization: evidence from an input-output analysis. Economies 8(2), 43 (2020a)

Ho, M.-T., Vuong, T.-T., Pham, T.-H., Luong, A.-P., Nguyen, T.-N., Vuong, Q.-H.: The internal capability of Vietnam social sciences and humanities: a perspective from the 2008-2019 dataset. Publications 8(2), 32 (2020b). https://doi.org/10.3390/publications 8020032

Hoang, L.A., Yeoh, B.S.A., Wattie, A.M.: Transnational labour migration and the politics of care in the Southeast Asian family. Geoforum 43(4), 733-740 (2012). https://doi.org/10.1016/j.geoforum. 2011.12.006

Hoang, V.M., Oh, J., Giang, K.B., Kien, V.D., Nam, Y.-S., Lee, C.O., Huong, T.T.G., Hoat, L.N.: Multiple vulnerabilities and maternal healthcare in Vietnam: findings from the Multiple Indicator Cluster Surveys, 2000, 2006, and 2011. Glob. Health Action 9(1), 29386 (2016). https://doi.org/10. 3402/gha.v9.29386

Hoang, N.T.T., Truong, H.Q., Dong, C.V.: Determinants of trade Between Taiwan and ASEAN countries: a PPML estimator approach. SAGE Open 10(2), 2158244020919516 (2020). https://doi.org/ $10.1177 / 2158244020919516$

Huy, H.T., Nonneman, W.: Economic effects of labor migration on agricultural production of farm households in the Mekong River Delta region of Vietnam. Asian Pac. Migr. J. 25(1), 3-21 (2016). https://doi.org/10.1177/0117196815621199

Huynh, V.K.: The economic benefits of surface water quality improvements: a case of channel in the Mekong Delta Vietnam. Int. J. Environ. Sustain. 9(2), 71-83 (2014). https://doi.org/10.18848/ 2325-1077/CGP/v09i02/55087

Ioannidis, J.P.A., Klavans, R., Boyack, K.W.: Thousands of scientists publish a paper every five days. Nature 561, 167-169 (2018). https://doi.org/10.1038/d41586-018-06185-8

Kikuchi, T., Yanagida, K., Vo, H.: The effects of mega-regional trade agreements on Vietnam. J. Asian Econ. 55, 4-19 (2018). https://doi.org/10.1016/j.asieco.2017.12.005

La, V.-P., Pham, T.-H., Ho, M.-T., Nguyen, M.-H., Nguyen, P., K.-L., Vuong, T.-T., Nguyen, H.-K. T., Tran, T., Khuc, Q., Ho, M.-T., \& Vuong, Q.-H.: Policy response, social media and science journalism for the sustainability of the public health system amid the COVID-19 outbreak: the Vietnam lessons. Sustainability 12(7), 2931 (2020). https://doi.org/10.3390/su12072931

Landhuis, E.: Scientific literature: information overload. Nature 535, 457-458 (2016). https://doi.org/10. 1038/nj7612-457a

Le, H.Q., Pomfret, R.: Technology spillovers from foreign direct investment in Vietnam: Horizontal or vertical spillovers? J. Asia Pac. Econ. 16(2), 183-201 (2011). https://doi.org/10.1080/13547860. 2011.564746

Le, H.T.T., Dao, Q.T.M., Pham, V.-C., Tran, D.T.: Global trend of open innovation research: a bibliometric analysis. Cogent Bus. Manag. (2019). https://doi.org/10.1080/23311975.2019.1633808

Madrueño, R., Tezanos, S.: The contemporary development discourse: analysing the influence of development studies' journals. World Dev. 109, 334-345 (2018). https://doi.org/10.1016/j.worlddev. 2018.05.005

Meschi, P.-X., Phan, T.T., Wassmer, U.: Transactional and institutional alignment of entry modes in transition economies. A survival analysis of joint ventures and wholly owned subsidiaries in Vietnam. Int. Bus. Rev. 25(4), 946-959 (2016). https://doi.org/10.1016/j.ibusrev.2015.12.005

Mitra, S., Palmer, M., Vuong, V.: Development and interdisciplinarity: a citation analysis. World Dev. 135, 105076 (2020). https://doi.org/10.1016/j.worlddev.2020.105076

Mont, D., Nguyen, V.C.: Disability and poverty in Vietnam. World Bank Econ. Rev. 25(2), 323-359 (2011). https://doi.org/10.1093/wber/lhr019 
Mulet-Forteza, C., Genovart-Balaguer, J., Mauleon-Mendez, E., Merigó, J.M.: A bibliometric research in the tourism, leisure and hospitality fields. J. Bus. Res. 101, 819-827 (2019). https://doi.org/10. 1016/j.jbusres.2018.12.002

NAFOSTED: Quyết định Phê duyệt Danh mục tạp chí quốc tế và quốc gia có uy tín trong lĩnh vực khoa học xã hội và nhân văn [Decision: Approved list of national and international scientific journals in social sciences and humanities] (2019). NAFOSTED https://nafosted.gov.vn/wp-content/uploads/ 2019/12/QD-Danh-muc-TCQTQG-KHXH-2019.11.25-FINAL-1.pdf. Accessed 28 Sept

Nguyen, V.C.: Can Vietnam achieve the millennium development goal on poverty reduction in high inflation and economic stagnation? Dev. Econ. 49(3), 297-320 (2011). https://doi.org/10.1111/j.1746-1049. 2011.00136.x

Nguyen, H.H.: Grassroots democracy and inequality reduction in rural Vietnam: the case of Thai Binh in 1997 and now. Asian J. Political Sci. 22(1), 71-92 (2014). https://doi.org/10.1080/02185377.2013. 879067

Nguyen, D.: Mapping knowledge domains of non-biomedical modalities: a large-scale co-word analysis of literature 1987-2017. Soc. Sci. Med. 233, 1-12 (2019). https://doi.org/10.1016/j.socscimed.2019.05. 044

Nguyen, V.T., Freeman, N.J.: State-owned enterprises in Vietnam: Are they 'crowding out' the private sector? Post-Communist Econ. 21(2), 227-247 (2009). https://doi.org/10.1080/14631370902778674

Nguyen, H.M., Nguyen, L.D.: The relationship between urbanization and economic growth: an empirical study on ASEAN countries. Int. J. Soc. Econ. 45(2), 316-339 (2018). https://doi.org/10.1108/ IJSE-12-2016-0358

Nguyen, C.H., Nordman, C.J.: Household entrepreneurship and social networks: panel data evidence from Vietnam. J. Dev. Stud. 54(4), 594-618 (2018). https://doi.org/10.1080/00220388.2017.1303668

Nguyen, T.V., Pham, L.T.: Scientific output and its relationship to knowledge economy: an analysis of ASEAN countries. Scientometrics 89(1), 107-117 (2011). https://doi.org/10.1007/s11192-011-0446-2

Nguyen, C.V., Pham, N.M.: Economic growth, inequality, and poverty in Vietnam. Asian-Pac. Econ. Lit. 32(1), 45-58 (2018). https://doi.org/10.1111/apel.12219

Nguyen, T.Q.T., Simkin, K.: Gender discrimination in Vietnam: the role of personal face. J. Gend. Stud. 26(6), 609-617 (2017). https://doi.org/10.1080/09589236.2015.1095083

Nguyen, C.V., Tran, A.: Poverty identification: practice and policy implications in Vietnam. Asian-Pac. Econ. Lit. 28(1), 116-136 (2014). https://doi.org/10.1111/apel.12046

Nguyen, V.C., Vu, H.L.: The impact of migration and remittances on household welfare: evidence from Vietnam. J. Int. Migr. Integr. 19(4), 945-963 (2018). https://doi.org/10.1007/s12134-018-0571-3

Nguyen, T.V., Bryant, S.E., Rose, J., Tseng, C.-H., Kapasuwan, S.: Cultural values, market institutions, and entrepreneurship potential: a comparative study of the United States, Taiwan, and Vietnam. J. Dev. Entrep. 14(01), 21-37 (2009). https://doi.org/10.1142/s1084946709001120

Nguyen, T.V., Le, C.Q., Tran, B.T., Bryant, S.E.: Citizen participation in city governance: experiences from Vietnam. Public Adm. Dev. 35(1), 34-45 (2015). https://doi.org/10.1002/pad.1702

Nguyen, N.A., Nguyen, N.M., Tran, N.B.: Corruption and economic growth, with a focus on Vietnam. Crime Law Soc. Change 65(4), 307-324 (2016). https://doi.org/10.1007/s10611-016-9603-0

Nguyen, D.T.H., Sun, S., Anwar, S.: A long-run and short-run analysis of the macroeconomic interrelationships in Vietnam. Econ. Anal. Policy 54, 15-25 (2017a). https://doi.org/10.1016/j.eap.2017.01.006

Nguyen, T.A., Vu, D.A., Van, V.P., Nguyen, T.N., Pham, T.M., Nguyen, H.T.T., Trinh, L.H., Nguyen, T.V., Hoang, L.K., Vu, T.D., Nguyen, T.S., Luong, T.T., Trinh, N.P., Hens, L.: Human ecological effects of tropical storms in the coastal area of Ky Anh (Ha Tinh, Vietnam). Environ. Dev. Sustain. 19(2), 745-767 (2017b). https://doi.org/10.1007/s10668-016-9761-3

Nguyen, T.V., Ho-Le, T.P., Le, U.V.: International collaboration in scientific research in Vietnam: an analysis of patterns and impact. Scientometrics 110(2), 1035-1051 (2017c). https://doi.org/10.1007/ s11192-016-2201-1

Nguyen, D.L., Grote, U., Nguyen, T.T.: Migration, crop production and non-farm labor diversification in rural Vietnam. Econ. Anal. Policy 63, 175-187 (2019). https://doi.org/10.1016/j.eap.2019.06.003

Nguyen, H.T.T., Giang, L.T., Pham, T.N.: Impacts of higher tobacco tax on output and employment in Vietnam. J. Econ. Dev. 22(1), 167-182 (2020a). https://doi.org/10.1108/JED-11-2019-0058

Nguyen, M.-H., Ho, M.-T., La, V.-P., Nguyen, Q.-Y.T., Ho, M.-T., Vuong, T.-T., Le, T.-T., Nguyen, M.-C., Vuong, Q.-H.: A scientometric study on depression among university students in East Asia: Research and system insufficiencies? Sustainability 12(4), 1498 (2020b)

Nguyen, T.T.H., Pham, H.-H., Vuong, Q.-H., Cao, Q.-T., Dinh, V.-H., Nguyen, D.D.: The adoption of international publishing within Vietnamese academia from 1986 to 2020: a review [https://doi.org/10. 1002/leap.1340]. Learned Publishing 34(2), 175-186 (2021). https://doi.org/10.1002/leap.1340 
Page, M.J., McKenzie, J.E., Bossuyt, P.M., Boutron, I., Hoffmann, T.C., Mulrow, C.D., Shamseer, L., Tetzlaff, J.M., Akl, E.A., Brennan, S.E., Chou, R., Glanville, J., Grimshaw, J.M., Hróbjartsson, A., Lalu, M.M., Li, T., Loder, E.W., Mayo-Wilson, E., McDonald, S., McGuinness, L.A., Stewart, L.A., Thomas, J., Tricco, A.C., Welch, V.A., Whiting, P., Moher, D.: The PRISMA 2020 statement: an updated guideline for reporting systematic reviews. BMJ 372, n71 (2021). https://doi.org/10.1136/ bmj.n71

Pham, A.D., Pham, H., Ly, K.C.: Double taxation treaties as a catalyst for trade developments: a comparative study of Vietnam's relations with ASEAN and EU member states. J. Risk Financ. Manag. 12(4), 172 (2019a)

Pham, K.T.H., Nguyen, L.H., Vuong, Q.-H., Ho, M.-T., Vuong, T.-T., Nguyen, H.-K.T., Vu, G.T., Nguyen, H.L.T., Tran, B.X., Latkin, C.A., Ho, C.S.H., Ho, R.C.M.: Health inequality between migrant and non-migrant workers in an industrial zone of Vietnam. Int. J. Environ. Res. Public Health 16(9), 1502 (2019b)

Phan, T.L., Pham, X.L., Le, N.H., Bui, A.T.T.: A co-citation and co-word analysis of social entrepreneurship research. J. Soc. Entrep. (2020). https://doi.org/10.1080/19420676.2020.1782971

Plan S.: Plan S making full and immediate Open Access a reality (2020). https://www.coalition-s.org/. Accessed 28 Oct

Szomszor, M., Pendlebury, D., Rogers, G.: Global Research Report Identifying Research Fronts in the Web of Science: From metrics to meaning. I. f. S. Information (2020).

The National Assembly of Viet Nam: Resolution on Five-Year Socio-Economic Development Plan from 2016-2020 The National Assembly of The Socialist Republic of Viet Nam. The National Assembly of Viet Nam (2016). http://www.chinhphu.vn/portal/page/portal/English/strategies/strategies details?categoryId=30\&articleId $=10057712$

Thu, V.H., Goto, D.: Does microfinance improve the household welfare of ethnic minorities? Evidence from Bac Kan province, Vietnam. Prog. Dev. Stud. 20(1), 65-83 (2020). https://doi.org/10.1177/ 1464993419886230

Thuy, N.: Vietnam gov't plans 7\% GDP growth in 2021-2025. Hanoi Times (2020a). http://hanoitimes. vn/vietnam-pm-targets-7-gdp-growth-in-2021-2025-socio-economic-plan-311732.html. Accessed $14 \mathrm{Oct}$

Thuy, N.: Vietnam gov't targets 2.5\% GDP growth for 2020. Hanoi Times (2020b). http://hanoitimes.vn/ vietnam-govt-targets-25-gdp-growth-for-2020-314101.html. Accessed 14 Oct

Tran, T.Q., Nguyen, S.H., Vu, H.V., Nguyen, V.Q.: A note on poverty among ethnic minorities in the Northwest region of Vietnam. Post-Communist Econ. 27(2), 268-281 (2015). https://doi.org/10. 1080/14631377.2015.1026716

Tran, T.Q., Nguyen, C.V., Van, V.H.: Does economic inequality affect the quality of life of older people in rural Vietnam? J. Happiness Stud. 19(3), 781-799 (2018a). https://doi.org/10.1007/ s10902-017-9851-4

Tran, T.Q., Tran, A.L., Pham, T.M., Van, V.H.: Local governance and occupational choice among young people: first evidence from Vietnam. Child Youth Serv. Rev. 86, 21-31 (2018b). https://doi.org/10. 1016/j.childyouth.2018.01.019

Tran, B.X., Nguyen, L.H., Turner, H.C., Nghiem, S., Vu, G.T., Nguyen, C.T., Latkin, C.A., Ho, C.S.H., Ho, R.C.M.: Economic evaluation studies in the field of HIV/AIDS: bibliometric analysis on research development and scopes (GAPRESEARCH). BMC Health Serv. Res. 19(1), 834 (2019a). https://doi.org/10.1186/s12913-019-4613-0

Tran, V.T., Nguyen, T.T., Tran, N.T.M.: Gender difference in access to local finance and firm performance: evidence from a panel survey in Vietnam. Econ. Anal. Policy 63, 150-164 (2019b). https:// doi.org/10.1016/j.eap.2019.05.004

Tran, T., Hoang, K.-L., La, V.-P., Ho, M.-T., Vuong, Q.-H.: Scrambling for higher metrics in the Journal Impact Factor bubble period: a real-world problem in science management and its implications. Probl. Perspect. Manag. 18(1), 48-56 (2020). https://doi.org/10.21511/ppm.18(1).2020.05

Truong, T.H.: The effects of corruption on the human capital accumulation process: evidence from Vietnam. Econ. Transit. Inst. Change 28(1), 69-88 (2020). https://doi.org/10.1111/ecot.12229

Tung, D.T.: Measurement of on-farm diversification in Vietnam. Outlook Agric. 46(1), 3-12 (2017). https://doi.org/10.1177/0030727016689512

Van, K.Q., Le, T.-A.T., Nguyen, T.H., Nong, D., Tran, B.Q., Meyfroidt, P., Tran, T., Duong, P.B., Nguyen, T.T., Tran, T., Pham, L., Leu, S., Thao, N.T.P., Huu-Dung, N., Dao, T.-K., Van, H.N., Nguyet, B.T.M., Nguyen, H.-S., Paschke, M.W.: Forest cover change, households' livelihoods, trade-offs, and constraints associated with plantation forests in poor upland-rural landscapes: evidence from North Central Vietnam. Forests 11(5), 548 (2020) 
Vo, D.H., Nguyen, T.C., Tran, N.P., Vo, A.T.: What factors affect income inequality and economic growth in middle-income countries? J. Risk Financ. Manag. 12(1), 40 (2019). https://doi.org/10. 3390/jrfm 12010040

Vuong, Q.-H.: The (ir)rational consideration of the cost of science in transition economies. Nat. Hum. Behav. 2(1), 5-5 (2018). https://doi.org/10.1038/s41562-017-0281-4

Vuong, Q.-H.: The financial economy of Viet Nam in an age of reform, 1986-2016. In: Volz, U., Morgan, P., Yoshino, N. (eds.) Routledge Handbook of Banking and Finance in Asia, pp. 201-222. Routledge (2019)

Vuong, Q.H.: Reform retractions to make them more transparent. Nature 582(7811), 149 (2020). https://doi. org/10.1038/d41586-020-01694-X

Vuong, Q.H., Nancy, K.N.: Resource curse or destructive creation in transition: evidence from Vietnam's corporate sector. Manag. Res. Rev. 37(7), 642-657 (2014). https://doi.org/10.1108/ MRR-12-2012-0265

Vuong, Q.H., Tran, T.: The Vietnamese Social Sciences at a Fork in the Road. De Gruyter (2019)

Vuong, T.-T., Nguyen, H.K.T., Ho, T.M., Ho, T.M., Vuong, Q.-H.: The (In)significance of socio-demographic factors as possible determinants of Vietnamese social scientists' contribution-adjusted productivity: preliminary results from 2008-2017 Scopus Data. Societies 8(1), 3 (2018). https://doi.org/ $10.3390 /$ soc 8010003

Vuong, T.T., Semerák, V., Vuong, Q.H.: The Vietnamese Economy at the Crossroads. In: Macdonald, R. (ed.) Southeast Asia and the ASEAN Economic Community, pp. 91-143. Palgrave Macmillan (2019). https://doi.org/10.1007/978-3-030-19722-3

Vuong, Q.-H., Do, M.-T., Pham, T.-V.-A., Do, T.-A., Doan, P.-T., Hoang, A.-D., Ta, T.-H., Le, Q.-A., Pham, H.-H.: The status of educational sciences in Vietnam: a bibliometric analysis from Clarivate Web of Science database between 1991 and 2018. Probl. Educ. 21st Century 78(4), 644-662 (2020a). https:// doi.org/10.33225/pec/20.78.644

Vuong, Q.-H., La, V.-P., Vuong, T.-T., Nguyen, H.-K.T., Ho, M.-T., Ho, M.-T.: What have Vietnamese scholars learned from researching entrepreneurship? A systematic review. Heliyon 6(4), e03808 (2020b). https://doi.org/10.1016/j.heliyon.2020.e03808

Vuong, Q.-H., Napier, N.K., Ho, T.M., Nguyen, V.H., Vuong, T.-T., Pham, H.H., Nguyen, H.K.T.: Effects of work environment and collaboration on research productivity in Vietnamese social sciences: evidence from 2008 to 2017 Scopus data. Stud. High. Educ. 44(12), 2132-2147 (2020c). https://doi.org/10. 1080/03075079.2018.1479845

Vuong, Q.H., La, V.P., Vuong, T.T., Hoang, P.H., Ho, M.T., Ho, M.T., Nguyen, H.K.T.: Multi-faceted insights of entrepreneurship facing a fast-growing economy: a literature review. Open Econ. 3(1), 25 (2020d). https://doi.org/10.1515/openec-2020-0002

Vuong, T.-T., Ho, M.-T., Nguyen, M.-H., Nguyen, T.-H.T., Nguyen, T.-D., Nguyen, T.-L., Luong, A.-P., Vuong, Q.-H.: Adopting open access in the social sciences and humanities: evidence from a developing nation. Heliyon 6(7), e04522 (2020e). https://doi.org/10.1016/j.heliyon.2020.e04522

Vuong, Q.-H., Bui, A.-T., La, V.-P., Nguyen, M.-H., Pham, H.-H., Pham, T.-H., Vu, T.-H., Vuong, T.-T., Ho, M.-T.: Mirror, mirror on the wall: is economics the fairest of them all?An investigation into the social sciences and humanities in Vietnam. Res. Eval. (2021). https://doi.org/10.1093/reseval/rvaa036

Walder, A.G., Nguyen, G.H.: Ownership, organization, and income inequality: market transition in rural Vietnam. Am. Sociol. Rev. 73(2), 251-269 (2008). https://doi.org/10.1177/000312240807300204

World Bank: Household Living Standards Survey 2004. World Bank (2020). https://microdata.worldbank. org/index.php/catalog/2370. Accessed 25 Oct

Publisher's Note Springer Nature remains neutral with regard to jurisdictional claims in published maps and institutional affiliations. 